\title{
A Review of Metal Silicides for Lithium-Ion Battery Anode Application
}

\author{
Bo Ding ${ }^{1} \cdot$ Zhenfei Cai $^{1} \cdot$ Zishan Ahsan $^{1}$ - Yangzhou Ma ${ }^{1,5}$. Shihong Zhang ${ }^{1} \cdot$ Guangsheng Song ${ }^{1} \cdot$ Changzhou Yuan $^{2}$. \\ Weidong Yang $^{3} \cdot$ Cuie Wen $^{4}$
}

Received: 18 March 2020 / Revised: 8 June 2020 / Published online: 3 July 2020

(c) The Chinese Society for Metals (CSM) and Springer-Verlag GmbH Germany, part of Springer Nature 2020

\begin{abstract}
Lithium batteries (LIBs) with low capacity graphite anode $\left(\sim 372 \mathrm{mAh} \mathrm{g}^{-1}\right)$ cannot meet the ever-growing demand for new energy electric vehicles and renewable energy storage. It is essential to replace graphite anode with higher capacity anode materials for high-energy density LIBs. Silicon ( $\mathrm{Si}$ ) is well known to be a possible alternative for graphite anode due to its highest capacity $\left(\sim 4200 \mathrm{mAh} \mathrm{g}^{-1}\right)$. Unfortunately, large volume change during lithiation and delithiation has prevented the $\mathrm{Si}$ anode from being commercialized. Metal silicides are a promising type of anode materials which can improve cycling stability via the accommodation of volume change by dispersing $\mathrm{Si}$ in the metal inactive/active matrix, while maintain greater capacity than graphite. Here, we present a classification of Si alloying with metals in periodic table of elements, review the available literature on metal silicide anodes to outline the progress in improving and understanding the electrochemical performance of various metal silicides, analyze the challenges that remain in using metal silicides, and offer perspectives regarding their future research and development as anode materials for commercial LIBs application.
\end{abstract}

Keywords Li-ion battery $\cdot$ Metal silicides $\cdot$ Anode materials $\cdot$ Electrochemical performance

\section{Introduction}

Available online at http://link.springer.com/journal/40195.

Bo Ding and Zhenfei Cai have contributed equally to this work.

Yangzhou Ma

yangzhou.ma@outlook.com

$\triangle$ Guangsheng Song

song_ahut@163.com

Changzhou Yuan

mse_yuancz@ujn.edu.cn

1 Key Laboratory of Green Fabrication and Surface Technology of Advanced Metal Materials, Ministry of Education, School of Materials Science and Engineering, Anhui University of Technology, Maanshan 243000, China

2 School of Materials Science and Engineering, University of Jinan, Jinan 250022, China

3 Future Manufacturing Flagship, Commonwealth Science and Industries Research Organization (CSIRO), Melbourne, VIC 3168, Australia

4 School of Engineering, RMIT University, Melbourne, VIC 3001, Australia

5 Electronic Materials Research Laboratory, Key Laboratory of the Ministry of Education, Xi' an Jiaotong University, Xi'an 710049, China
Lithium-ion secondary batteries, with high energy density (per weight and volume), and the ability to deliver high power output, have dominated the power source field for portable electronic devices [1-6]. However, current lithium battery technology cannot satisfy the increasingly demanding energy and power requirements of electric vehicles and power storage for certain renewable energy sources such as solar and wind energy. Thus, the development of batteries with high gravimetric and volumetric energy and power density has stimulated intense research interest in recent years. Many efforts have been made in exploring various battery anode/ cathode materials, electrolyte, and separators [7-11]. One particular focus area is the development of new anode materials, with substantially higher energy densities, to replace currently existing graphite anodes which cannot fulfill the higher storage capacity requirements [9]. In this context, $\mathrm{Si}$ offers a theoretical maximum specific capacity of about $4200 \mathrm{mAh} \mathrm{g}^{-1}$ which is over tenfold greater than that of graphite $\left(370 \mathrm{mAh} \mathrm{g}^{-1}\right)$ [12]. In addition to its outstanding capacity, $\mathrm{Si}$ is the second most abundant element in the Earth's crust with a global production of 
over 7 million tonnes in 2012 [US geological survey]. Due to these attributions, much attention has been given to using $\mathrm{Si}$ as $\mathrm{Li}$-ion battery anode material.

The use of pure silicon as an anode material in lithium-ion batteries has been limited by its high electrical resistivity, low diffusion coefficient of $\mathrm{Li}^{+}$within the $\mathrm{Si}$ structure, and most significantly, the large volume change during the alloying/de-alloying processes which ultimately leads to fatigue and degradation of the electrode [13-15]. The large volume change can be attributed to the formation of a series of $\mathrm{Si}-\mathrm{Li}$ compounds according to the basic reaction: $x \mathrm{Li}+\mathrm{Si}$ $\leftrightarrow \mathrm{Li}_{x} \mathrm{Si}(x=1.71,3.25$ or 4.4$)$. With increasing $\mathrm{Li}$ insertion in the host lattice, the volume per Si atom in the unit cell for each compound increases progressively. For example, the volume per $\mathrm{Si}$ atom in cubic $\mathrm{Li}_{22} \mathrm{Si}_{5}\left(\mathrm{Li}_{4.4} \mathrm{Si}\right)$ structure is $0.0824 \mathrm{~nm}^{3}$, four times higher than that of the parent $\mathrm{Si}$ atom $\left(0.020 \mathrm{~nm}^{3}\right)$, which means a volume expansion $310 \%$ of the Si lattice takes place [12]. This large volume change during lithiation causes high internal stress, electrode pulverization, and subsequent loss of electrical contact between the active material and current collector, resulting in poor reversibility and rapid capacity fade [9]. Clearly, these issues are detrimental to the use of silicon in batteries where commercial market forces require long cycle lifetimes in the range of several thousand cycles.

In order to improve the performance of $\mathrm{Si}$ anodes (i.e., stabilization of high capacity and increased cycle lifetimes), several approaches have been developed to alleviate the detrimental effect of large volume change generated during the alloying/de-alloying processes. These approaches include: (a) particle size reduction to nanometer scale [16]; (b) Si/C nanocomposite structures [17]; (c) high porosity structures; (d) alternative binders [18]; and (e) metal-Si intermetallic compounds. This manuscript will focus on the applications of metal-Si intermetallic compounds (i.e., metal silicides) as an approach to obtain better capacity retention and cycle life.

Metal silicides are widely used in silicon integrated circuits as contacts and interconnections. In addition to microelectronics application, metal silicides are also important for other applications such as thermoelectric devices and jet engines. Of all these applications, we are particularly interested in the application of silicides in lithium-ion batteries.

This paper reviews the available literature on metal silicide anode materials published from the first use in 1999 [19], explores some of the recent development regarding to their synthesis and microstructural characterization/ electrochemical performance in order to assess the viability of this type of material as a replacement for graphite in Li-ion batteries, and gives a general outlook for the application of metal silicides in LIBs. After analyzing the literature data, the challenges and future research directions/
PERIODIC TABLE OF ELEMENTS

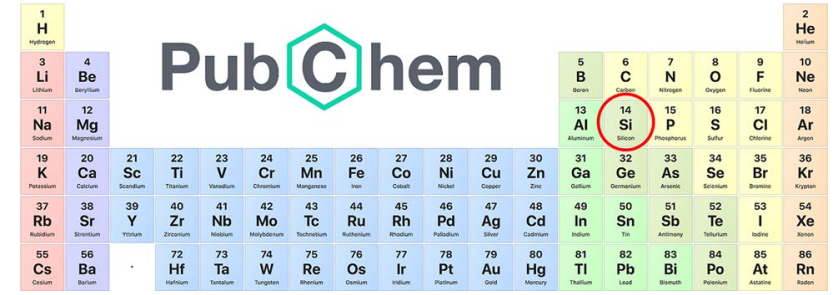

Fig. 1 Metal elements used for the formation of silicides in the M-Si system

Table 1 Typical silicides of elements in metal groups

\begin{tabular}{|c|c|c|}
\hline Elements & Group & Product \\
\hline $\mathrm{Li}$ & I & $\mathrm{Li}_{22} \mathrm{Si}_{5} \mathrm{Li}_{13} \mathrm{Si}_{4} \mathrm{Li}_{7} \mathrm{Si}_{3} \mathrm{Li}_{12} \mathrm{Si}_{7} \mathrm{LiSi}$ \\
\hline $\mathrm{Ca}$ & II & $\mathrm{Ca}_{2} \mathrm{Si} \mathrm{Ca}_{5} \mathrm{Si}_{3} \mathrm{CaSi} \mathrm{CaSi}_{2}$ \\
\hline $\mathrm{Mg}$ & II & $\mathrm{Mg}_{2} \mathrm{Si}$ \\
\hline $\mathrm{Ti}$ & III & $\mathrm{Ti}_{3} \mathrm{Si} \mathrm{Ti}_{5} \mathrm{Si}_{4} \mathrm{TiSi} \mathrm{TiSi}_{2}$ \\
\hline $\mathrm{Co}$ & III & $\mathrm{Co}_{2} \mathrm{Si} \mathrm{CoSi} \mathrm{Co}{ }_{2} \mathrm{Si}_{3} \mathrm{CoSi}_{2}$ \\
\hline $\mathrm{Fe}$ & III & $\mathrm{Fe}_{3} \mathrm{Si} \mathrm{Fe}_{5} \mathrm{Si}_{3} \mathrm{FeSi} \mathrm{FeSi}_{2}$ \\
\hline $\mathrm{Mn}$ & III & $\mathrm{Mn}_{3} \mathrm{Si} \mathrm{Mn}_{5} \mathrm{Si}_{2} \mathrm{MnSi} \mathrm{MnSi}_{2}$ \\
\hline $\mathrm{Ni}$ & III & $\mathrm{Ni}_{2} \mathrm{Si} \mathrm{Ni}_{3} \mathrm{Si}_{2} \mathrm{NiSi} \mathrm{NiSi}_{2}$ \\
\hline $\mathrm{Cr}$ & III & $\mathrm{Cr}_{3} \mathrm{Si} \mathrm{Cr}_{5} \mathrm{Si}_{3} \mathrm{CrSi} \mathrm{CrSi}_{2}$ \\
\hline $\mathrm{Cu}$ & III & $\mathrm{Cu}_{3} \mathrm{Si} \mathrm{Cu}_{15} \mathrm{Si}_{4} \mathrm{Cu}_{5} \mathrm{Si}$ \\
\hline $\mathrm{Ag}$ & III & $\mathrm{Ag}+\mathrm{Si}$ \\
\hline $\mathrm{Al}$ & IV & $\mathrm{Al}+\mathrm{Si}$ \\
\hline $\mathrm{Sn}$ & IV & $\mathrm{Sn}+\mathrm{Si}$ \\
\hline $\mathrm{Ge}$ & IV & $\mathrm{Ge}_{1-x} \mathrm{Si}_{x}(x=0-1$ at $\%)$ \\
\hline
\end{tabular}

perspectives in the development of metal-silicide anodes are also indicated in this review.

\section{Types of Metal Silicides and Their Effects on Electrochemical Properties}

Metals (Ms) can be divided into four groups, as shown in the periodic table (Fig. 1). These are alkali metals (Group-I), alkaline earth metals (Group-II), transition metals (Group-III), and other metal elements (Group-IV). Metals in Groups I-III react with silicon to form one or more silicides except for $\mathrm{Be}, \mathrm{Zn}, \mathrm{Ag}, \mathrm{Cd}, \mathrm{Au}$, and $\mathrm{Hg}$. Metals in Group-IV do not react with silicon to form silicides, but they can form either a two phase $(\mathrm{M}+\mathrm{Si})$ structure such as $\mathrm{Al}-\mathrm{Si}, \mathrm{Ag}-\mathrm{Si}$, and $\mathrm{Sn}-\mathrm{Si}$ or solid solution like $\mathrm{Si}-\mathrm{Ge}$ system. Typical metal silicide products are listed in Table 1.

Metal silicides are classified into two types in this work, according to lithium inactive/active metals. One is $\mathrm{Mi}_{x} \mathrm{Si}_{y}$ where Mi represents an inactive metal element such 
as $\mathrm{Ti}$ (which does not form Li-containing compounds). The other is $\mathrm{Ma}_{x} \mathrm{Si}_{y}$ where Ma represents an active metal element such as $\mathrm{Mg}$ (which does form Li-containing compounds). Members of the $\mathrm{Mi}_{x} \mathrm{Si}_{y}$ compound family can be used as anodes by virtue of the following reversible reaction $[20,21]$ :

$\mathrm{Mi}_{x} \mathrm{Si}_{y}+y \mathrm{Li}=y \mathrm{LiSi}+x \mathrm{Mi}$.

In this context, the Mi plays a buffering role but does not actively participate in compound formation with the $\mathrm{Li}$ atoms, whereas in the case of $\mathrm{Ma}_{x} \mathrm{Si}_{y}$, the reversible reaction is shown in Eq. 2 [22, 23]:

$\mathrm{Ma}_{x} \mathrm{Si}_{y}+(x+y) \mathrm{Li}=y \mathrm{LiSi}+x \mathrm{LiMa}$.

For this scenario, both the $\mathrm{Si}$ and $\mathrm{Ma}$ are required for reaction with the Li cations. Formation of lithiated phase compounds occurs at different voltages, and thus, one component can act as a buffer for the other one. In these electrochemical reactions, the original anode materials can be converted into a $\mathrm{Li}-\mathrm{Si}$ compound and a second displaced phase. The displaced phase, existing in the form of either pure metal or compound, can serve as a buffering matrix reducing the effect of the lithiated phase volume expansion during repeated cycling tests.

\subsection{Binary Metal Silicides}

Of all metal silicides, binary metal silicides drew the first attention on improving the electrochemical performance of silicon in lithium batteries. This section sorts out and discusses electrochemical performance of active and inactive binary metal silicide anodes reported so far.

\subsubsection{Active Metal-Containing $\mathrm{Ma}_{x} \mathrm{Si}_{y}$}

2.1.1.1 Mg-Si Magnesium and silicon are both naturally abundant, lightweight and inexpensive, and lithium can be inserted into $\mathrm{Mg}$ and $\mathrm{Si}$ at room temperature, which are desirable features for a battery material [24]. It has been reported that magnesium silicide possesses a highly specific capacity of $1370 \mathrm{mAh} \mathrm{g}^{-1}$ at $10 \mathrm{~mA} \mathrm{~g}^{-1}$, equal to $3.9 \mathrm{Li}$ per $\mathrm{Mg}_{2} \mathrm{Si}$. However, experimental testing showed that the capacity faded rapidly to less than $100 \mathrm{mAh} \mathrm{g}^{-1}$ after 10 cycles at $30 \mathrm{~mA} \mathrm{~g}^{-1}$ [19]. To understand the capacity fade, some reaction mechanisms were proposed by Roberts et al. [22]. During lithiation, the insertion of $\mathrm{Li}$ into $\mathrm{Mg}_{2} \mathrm{Si}$ occurs first, and $\mathrm{Li}_{2} \mathrm{MgSi}$ with a cubic fluorite type structure is then formed along with the extraction of $\mathrm{Mg}$ from $\mathrm{Mg}_{2} \mathrm{Si}$. $\mathrm{Li}_{2} \mathrm{MgSi}$ is then converted to $\mathrm{Li}-\mathrm{Mg}$ and $\mathrm{Li}-\mathrm{Si}$ alloys at low current densities and low potentials during the lithiation process $[22,25]$. The presence of $\mathrm{Li}-\mathrm{Mg}$ and $\mathrm{Mg}$ phases at the end of extraction was confirmed through X-ray diffraction (XRD) data analysis [19]. These irreversible reactions are attributed to the capacity fade, since lithium is then bound up inside the anode and thus not available for battery reactions. Moreover, $\mathrm{Li}$ insertion into the remaining $\mathrm{Mg}$ phase results in volume change, aggravating the cracking and disintegration of electrodes.

Further to the above issues, $\mathrm{Mg}$ is very chemically active and easily oxidized during mechanical alloying or processing to form the $\mathrm{MgSi}$ starting material. This oxide layer can decrease the electrochemical performance of the final $\mathrm{Mg}_{2} \mathrm{Si}$ alloy. In order to overcome this issue, high purity nanocrystalline $\mathrm{Mg}_{2} \mathrm{Si}$ was obtained by hydrogendriven chemical reaction [26]. $\mathrm{Mg}_{2} \mathrm{Si}$ synthesized using this methodology exhibited an improved Li-ion storage ability because of its recorded initial capacity of 1095 $\mathrm{mAh} \mathrm{g}^{-1}$ at $100 \mathrm{~mA} \mathrm{~g}^{-1}$ current density, and the discharge capacity remained stable at $406 \mathrm{mAh} \mathrm{g}^{-1}$ after 60 cycles. A metathesis reaction route to obtain fine $\mathrm{Mg}_{2} \mathrm{Si}$ particles was reported by Itahara et al. [27]. It is well known that $\mathrm{Mg}_{2} \mathrm{Si}$ easily suffers from oxidation, so the effect of oxidation on the electrochemical performance of $\mathrm{Mg}_{2} \mathrm{Si}$ was also investigated [27]. As shown in Fig. 2, the initial discharge capacity of oxygen-free fine $\mathrm{Mg}_{2} \mathrm{Si}$ particles C-1 (C-2) was 740 (about 480) $\mathrm{mAh} \mathrm{g}^{-1}$ at $100 \mathrm{~mA} \mathrm{~g}^{-1}$, and the reversible capacity is still more than 300 (less than 200) $\mathrm{mAh} \mathrm{g}^{-1}$ after 100 cycles. The studies by Itahara et al. verified that oxidation of the $\mathrm{Mg}_{2} \mathrm{Si}$ would be disadvantageous to the specific capacity and cycling stability.

Although $\mathrm{Mg}_{2} \mathrm{Si}$ has a satisfactory capacity, it decays sharply at the beginning of cycles, which seriously affects the electrochemical performance. Tamirat et al. [28] have designed and synthesized carbon-coated $\mathrm{Mg}_{2} \mathrm{Si}$ nanoparticles by mechanically activated annealing and thermal vapor deposition which focused to enhance its cyclic stability. As shown in Fig. 3, the specific discharge/ charge capacity of pure $\mathrm{Mg}_{2} \mathrm{Si}$ was $1390 / 744 \mathrm{mAh} \mathrm{g}^{-1}$ (the initial coulomb efficiency was $53.53 \%$ ) and vanished about 15 th cycle. The reasons for this phenomenon are due to the volume expansion of $\mathrm{Mg}_{2} \mathrm{Si}$ during the intercalation/ deintercalation, the irreversible decomposition of $\mathrm{Mg}_{2} \mathrm{Si}$ and the partially irreversible $\mathrm{Li}-\mathrm{Mg}$ alloy [29]. Meanwhile, the carbon-coated $\mathrm{Mg}_{2} \mathrm{Si}$-active materials, which increase the conductivity and electronic contact, show excellent cycling performance and rate performance (Fig. 3b, c). The initial cycle discharge/charge capacities of 1199/726 mAh $\mathrm{g}^{-1}$ (with coulomb efficiency $60.55 \%$ ) were maintained to $470.9 / 470.1 \mathrm{mAh} \mathrm{g}^{-1}$ in the 500th cycle. Furthermore, the anode material shows $380 \mathrm{mAh} \mathrm{g}^{-1}$ at a $2 \mathrm{~A} \mathrm{~g}^{-1}$ current density.

2.1.1.2 Si-Ge Germanium (Ge) is a semiconductor with relative high electrical conductivity, and moreover, the 

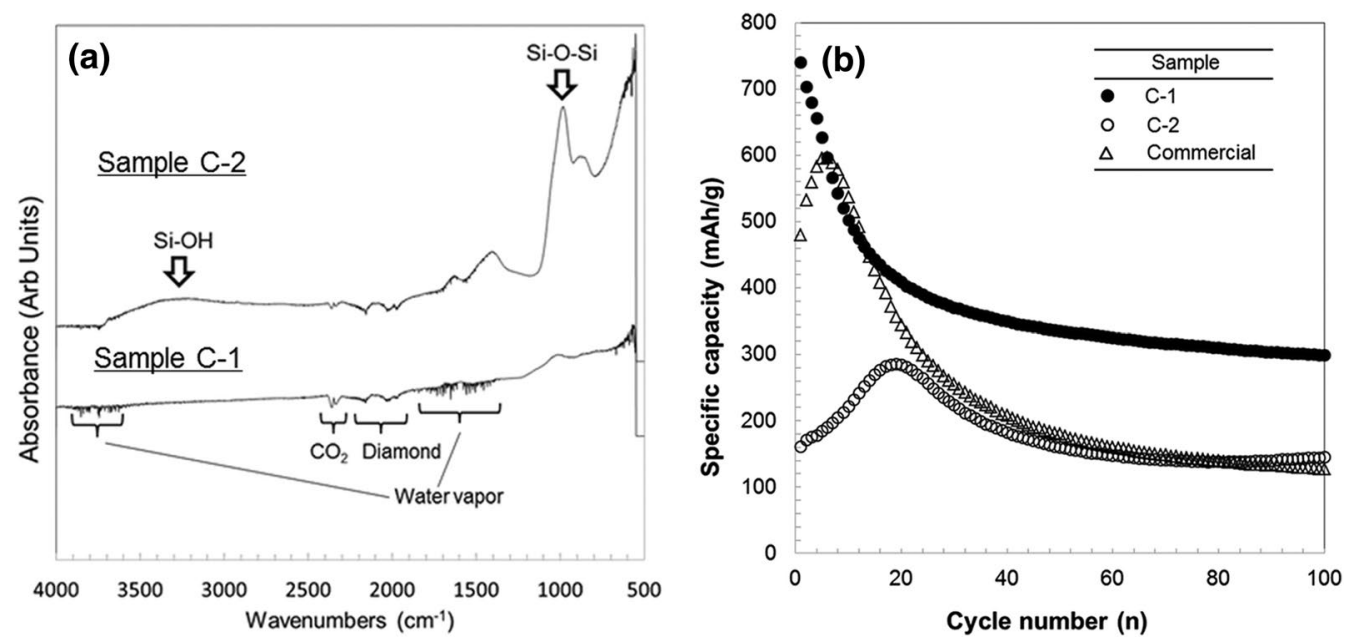

Fig. 2 a IR spectra for samples C-1 and C-2 measured in air with the attenuated total reflectance (ATR) method. b Discharge capacity for samples C-1 and C-2 over 100 cycles evaluated at a constant current of $100 \mathrm{~mA} \mathrm{~g}^{-1}$ with a voltage window of $0.02-1.5 \mathrm{~V}\left(\mathrm{vs}\right.$. Li/Li $\mathrm{L}^{+}$). The commercial sample is an $\mathrm{Mg}_{2} \mathrm{Si}$ reagent powder with particle diameters less than $53 \mu \mathrm{m}$ [27]
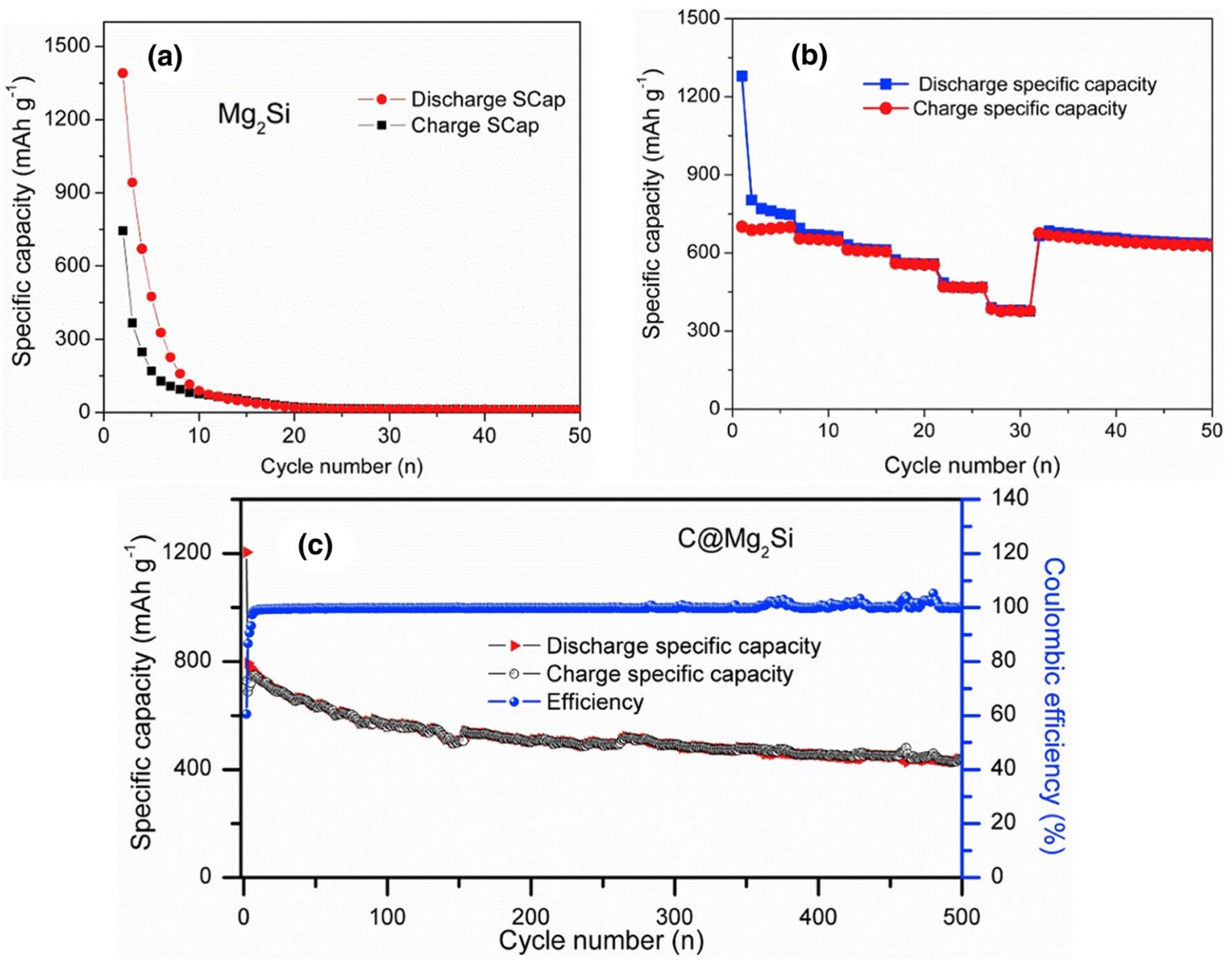

Fig. 3 a Cycling performance of Pure $\mathrm{Mg}_{2} \mathrm{Si}$. b Rate performance of carbon-coated $\mathrm{Mg}_{2} \mathrm{Si}$ electrode at different current density. c Cycling performance of carbon-coated $\mathrm{Mg}_{2} \mathrm{Si}$ with its corresponding coulombic efficiency measured at $100 \mathrm{~mA} \mathrm{~g}^{-1}$ [28] 
diffusivity of $\mathrm{Li}$ in $\mathrm{Ge}$ at room temperature is about 400 times higher than that in silicon. Therefore, Si-Ge composites have been researched as high-performance anode materials for lithium-ion batteries. Duveau et al. prepared $\mathrm{Ge}_{x} \mathrm{Si}_{1-x}$ by mechanosynthesis, all the active material increase the capacity compared with Ge. And all the synthesized $\mathrm{Ge}_{x} \mathrm{Si}_{1-x}$ electrode materials showed excellent cycling performance and rate performance compared to pure $\mathrm{Si}$ electrodes [30]. However, the volume expansion still exists due to the increase in silicon content. To solve this issue, nanostructured metal silicides such as nanotube, nanowires, core-shell nanoparticles, and hollow mesoporous have been studied. Song et al. [31] reported a nanotube heterostructure array, as shown in Fig. 4a, b, with a high-capacity Si inner layer and a highly conductive Ge outer layer produced by chemical vapor deposition (CVD. The Si/Ge composite nanotube array electrode exhibits higher initial specific capacity and coulombic efficiency (88.5\%) than those of previously reported pure $\mathrm{Ge}$ electrodes, and displayed good retention of capacity ( $85 \%$ after 50 cycles) and twice the capacity at a $3 \mathrm{C}$ rate compared to the $\mathrm{Si}$ electrode in spite of a reduced initial capacity (Fig. 3c, d). These outstanding electrochemical performances are due to the reduced maximum hoop strain, enhanced electric conductivity, and accelerated $\mathrm{Li}$ diffusion of this $\mathrm{Si} / \mathrm{Ge}$ composite electrode. Using the volume expansion characteristics of $\mathrm{Si} / \mathrm{Ge}$ anode materials during the lithiation and delithiation, Stokes et al. [32, 33] reported an axial Si-Ge heterostructure nanowires. The heterostructure nanowires were prepared by two steps. First, synthesize a nanowire through an injection of phenyl silane onto an evaporated layer of $\mathrm{Sn}$ on stainless steel. Then, triphenylgermane was injected to yield axial heterostructures (Fig. 4f). During the charge and discharge process, the heterostructure nanowires can form a porous network of uniform $\mathrm{Si}_{1-x} \mathrm{Ge}_{x}$ compounds. Owing to this special process, $\mathrm{Si}_{1-x} \mathrm{Ge}_{x}$ composite anode exhibits high initial capacities of $1644 \mathrm{mAh} \mathrm{g}^{-1}$, excellent capacity retention of $71.8 \%$ after 400 cycles and high power rate of $600 \mathrm{mAh} \mathrm{g}^{-1}$ at $10 \mathrm{C}$ (Fig. 4e).

$\mathrm{Si} / \mathrm{Ge}$ porous nanorod arrays utilizing $\mathrm{ZnO}$ nanorod arrays as a sacrificial template and co-sputtering method have also been investigated as an anode material for
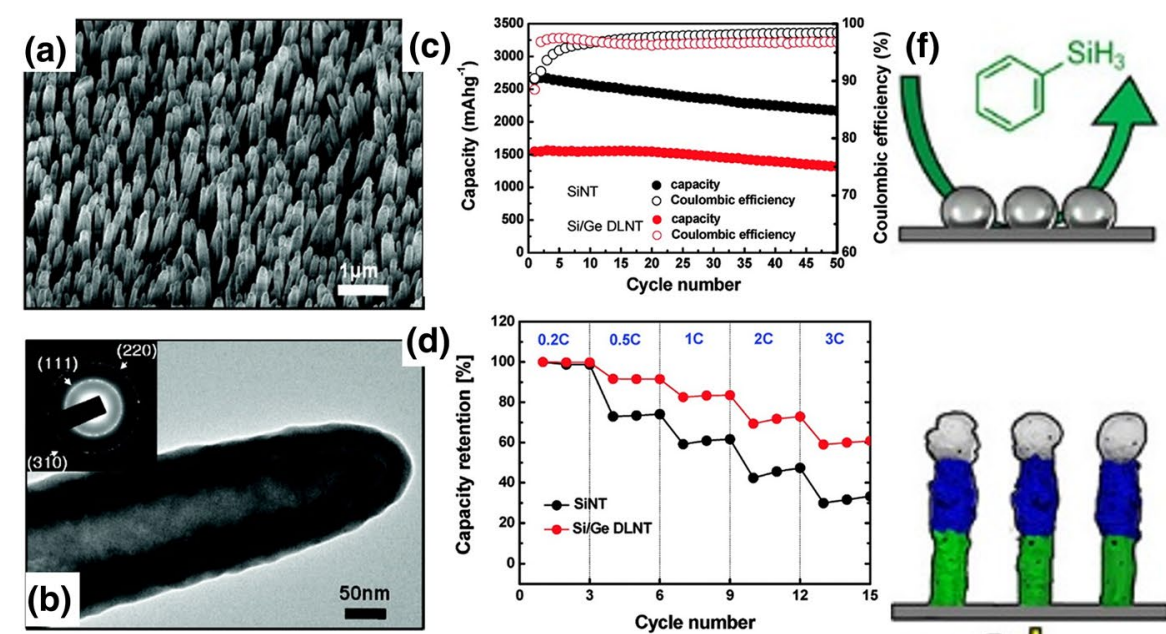

(d)

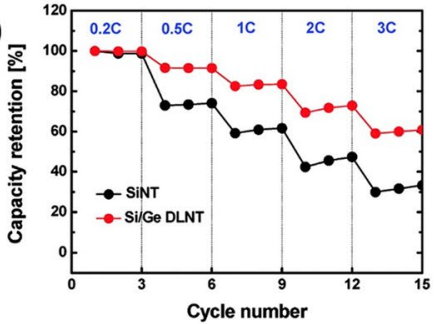

(e)

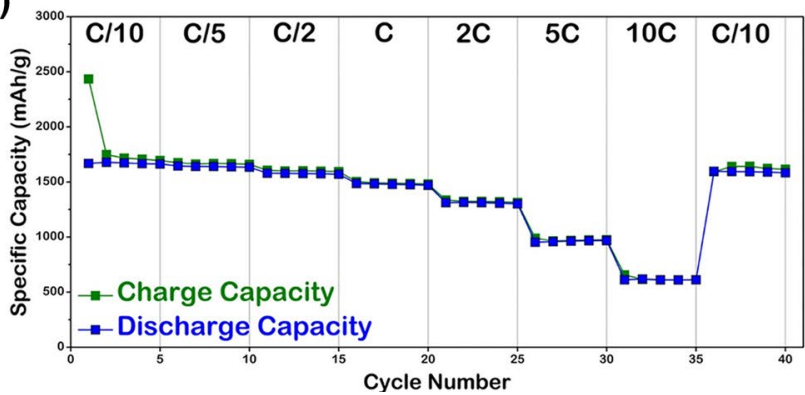

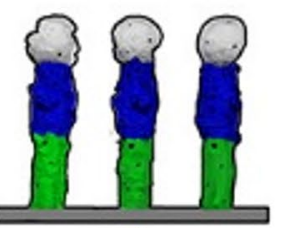

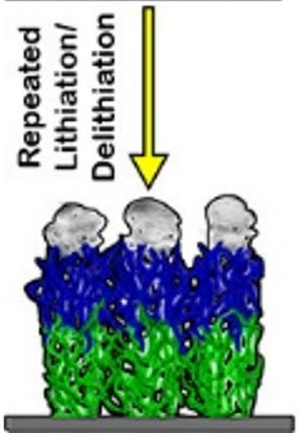

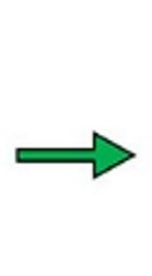
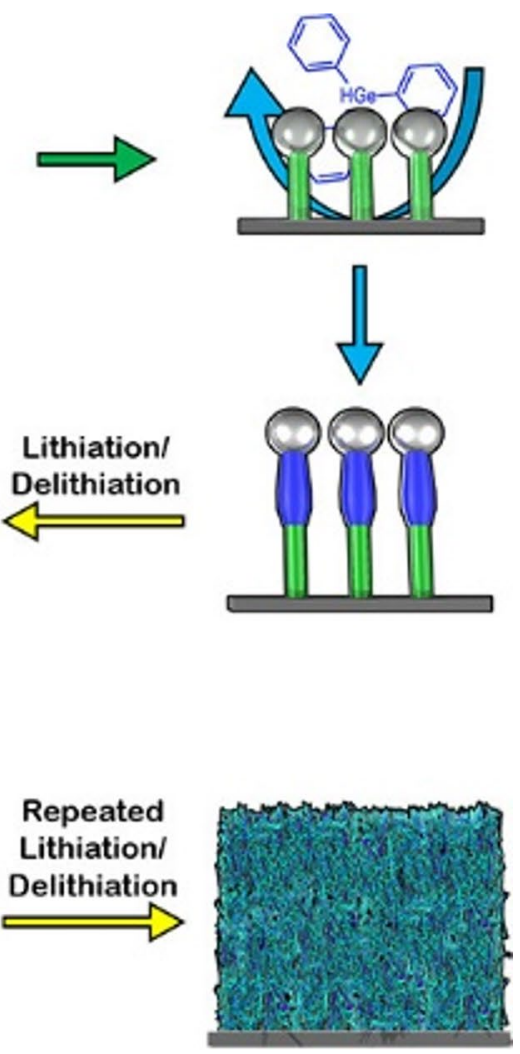

Fig. 4 a SEM images of a vertically aligned Si/Ge nanotube array on a stainless steel substrate. b Magnification TEM images of a single Si/ $\mathrm{Ge}$ nanotube. Inset of $\mathbf{b}$ shows selective area electron diffraction pattern. $\mathbf{c}$ Cycle performances. $\mathbf{d}$ Rate capabilities of $\mathrm{Si}$ nanotube and $\mathrm{Si} / \mathrm{Ge}$ nanotube array electrodes at various $\mathrm{C}$ rates [31]. e Charge and discharge capacities $\left(\mathrm{mAh} \mathrm{g}^{-1}\right)$ of Si-Ge heterostructure nanowires demonstrated at different current rates. f Overview of the synthetic protocol used to prepare $\mathrm{Sn}$-seeded $\mathrm{Si}-\mathrm{Ge} \mathrm{hNW}$ directly from current collectors and the changes in morphology due to repeated cycling with Li from segmented crystalline structures to an amorphous alloyed network after 50 cycles [33] 
lithium-ion batteries [34]. This type of anode showed enhanced performance (about $1000 \mathrm{mAh} \mathrm{g}^{-1}$ after 100 cycles) over bare Si porous nanorod arrays (nearly $600 \mathrm{mAh}$ $\mathrm{g}^{-1}$ after 100 cycles) because of good contact between the porous nanorod arrays and the current collector. The greatly improved conductivity and lithium-ion diffusivity in SiGe layer caused by addition of Ge may be responsible for the enhanced performance. However, the SiGe porous nanorod arrays show a first Coulombic efficiency of $31.8 \%$, which is significantly lower than the data of $\mathrm{Si} / \mathrm{Ge}$ double-layered nanotube arrays (88.5\%). This could be due to the formation of a substantial solid electrolyte interphase (SEI) and other side reactions, since co-sputtering process may suffer from more oxidation compared to CVD method [34].

2.1.1.3 Ca-Si According to the research of Netz et al. [35], $\mathrm{CaSi}_{2}$ was reported to show a high reversible capacity, corresponding to $1.15 \mathrm{Li} \mathrm{mol}^{-1}$. Based on the predicted $\mathrm{Ca}-\mathrm{Si}-\mathrm{Li}$ room-temperature phase diagram, the reaction mechanism was proposed for the $\mathrm{Li}$ insertion in a $\mathrm{CaSi}_{2}$ anode as follows [23]:

$10.8 \mathrm{Li}+\mathrm{CaSi}_{2} \rightarrow \mathrm{Li}_{2} \mathrm{Ca}+2 \mathrm{Li}_{4.4} \mathrm{Si}$.

A charge capacity above $1500 \mathrm{mAh} \mathrm{g}^{-1}$ was exhibited when cycling over a wide voltage window of $0.005-1.5 \mathrm{~V}$, which was reduced to $310 \mathrm{mAh} \mathrm{g}^{-1}$ after 10 cycles [23]. Beyond mechanical cracking during Li insertion/ extraction, lower melting temperatures, high ductility and elastic modulus of $\mathrm{Ca}-\mathrm{Si}$ alloy matrices were regarded as the other reason for its poor cycle life. Under the stated test conditions, the material cannot tolerate large volume changes and consequently severe capacity fade during initial cycling is observed.

2.1.1.4 Si-Ag Lithium insertion in $\mathrm{SiAg}$ powders produced by mechanical alloying has also been investigated [36]. The results of X-ray diffraction (XRD) and scanning electron microscopy (SEM) showed that nanoscaled Si particles were uniformly dispersed in a ductile $\mathrm{Ag}$ matrix, but a stable capacity of only $280 \mathrm{mAh} \mathrm{g}^{-1}$ was obtained [36]. The poor cycling was due to the anode pulverization which was caused during the Li-insertion volume change. This result means that the addition of Ag cannot accommodate the large volume changes of the Si. Other SiAg anodes prepared by electroless deposition of Ag particles on commercial Si powder were also characterized by SEM, XRD, X-ray photoelectron spectroscopy (XPS), cyclic voltammetry (CV), liquid solid chromatography (LSC) and electrochemical impedance spectroscopy (EIS) [37]. An improved performance of this $\mathrm{AgSi}$ anode was attributed to formation of an SEI film, which was believed to keep binding to the Si particles during lithium insertion and thereby ensuring good electric contact between particles as well as reducing fragmentation through the volume expansion process [37]. Similarly, the effect of thin alumina deposits on top of Si-based nanowires has been studied. A thin alumina deposit can act as a substitute for the SEI, preventing electrolyte decomposition and prolonging the lifetime of the anode [38].

2.1.1.5 Si-Sn Among metal silicide anode materials, the $\mathrm{Si} / \mathrm{Sn}$ binary system is considered to be one of the potential silicides because $\mathrm{Sn}$ as active matrix has high theoretical capacity of about $993 \mathrm{mAh} \mathrm{g}^{-1}$ for $\mathrm{Li}_{4.4} \mathrm{Sn}$, and $\mathrm{Sn}$ also shows excellent conductivity of $9.2 \times 10^{4} \mathrm{~S} \mathrm{~cm}^{-1}$ at $20^{\circ} \mathrm{C}$ which is much higher than Si. However, the $\mathrm{Si}$ and $\mathrm{Sn}$ interact with $\mathrm{Li}^{+}$to form alloys instead of intercalating which gives rise to serious volume expansion during the reversible cycling reactions $[39,40]$. In order to alleviate alloying-induced volume expansion, several strategies were reported such as designing the Si-Sn nanocomposites $[41,42]$ thin film [43, 44] and $\mathrm{Si} / \mathrm{Sn} / \mathrm{C}$ composite [45] with the aim to improve their electrochemical performance. Xiao et al. [42] have demonstrated that the $\mathrm{Si}$ and $\mathrm{Sn}$ are incompatible, and the existence of Sn can improve the conductivity and absorb the elastic strain energy to prevent crack growth. Zhong et al. [46] added Sn nanoparticles to the silicon-based anode which can reduce the active material surface area while maintaining its nanostructure. Therefore, the as-prepared nanocomposite showed the specific capacity of $1500 \mathrm{mAh}$ $\mathrm{g}^{-1}$ and preferable initial Coulomb efficiency of $81 \%$ and maintained the capacity of $110 \mathrm{mAh} \mathrm{g}^{-1}$ after 100 cycles. In order to achieve homogeneous mixing between $\mathrm{Si}$ and $\mathrm{Sn}$, Yao et al. [39] synthesized Si-Sn nanocomposites by chemical reduction. The prepared $\mathrm{Si}-\mathrm{Sn}$ sample exhibited a discharge capacity of $2245 \mathrm{mAh} \mathrm{g}^{-1}$ with the initial Coulombic efficiency of $61.5 \%$ and exhibited excellent cycling stability with a reversible capacity of $700 \mathrm{mAh} \mathrm{g}^{-1}$ after 200 cycles. Moreover, a hierarchical microporous Si/ Sn composite was reported by Hao et al. [47]. The porescontaining $\mathrm{Si}_{85} \mathrm{Sn}_{15}$ showed a $1600 \mathrm{mAh} \mathrm{g}^{-1}$ after 70 cycles, even at a current density of up to $3000 \mathrm{~mA} \mathrm{~g}^{-1}$. Due to the special hierarchical microporous structure, the diffusion distance of $\mathrm{Li}^{+}$can be shortened and the void space can serve as additional buffer for the electrode materials during the cycling. In addition, the diffusion rate was increased owing to the existence of $\mathrm{Sn}$.

2.1.1.6 Other $\mathrm{Ma}_{x} \mathrm{Si}_{y}$ Other active metals, such as $\mathrm{Al}$ [48], Zn [49], were investigated as quite important alloy components in the recent literature. Zhang et al. [50] prepared multilayer Si/Al film with 3D nanostructure which exhibited the capacity as high as $1015 \mathrm{mAh} \mathrm{g}^{-1}$ after 120 cycles at a current density of $4.1 \mathrm{~A} \mathrm{~g}^{-1}$. This work provided a new idea for the development of $\mathrm{Al} / \mathrm{Si}$ anode. Tahmasebi 
et al. [51] synthesized Al-Si thin film and found that the multiple thin film had quite stable structure, providing a long-term cycling stability. Transition metals $(\mathrm{Cr}, \mathrm{Fe} \mathrm{Mn}$, $\mathrm{Ni}$, etc.) were generally used in the Al-Si alloy to stabilized the amorphous structure and improve the electrochemical performance [52]. Furthermore, $\mathrm{Zn}$ was introduced into the $\mathrm{Si}$ anode to improve the cycle stability and rate capability by virtue of their similar atomic sizes, bonding characteristics and electronegativity [53].

\subsubsection{Inactive Metal-Containing $\mathrm{Mi}_{x} \mathrm{Si}_{y}$}

2.1.2.1 Ni-Si Nickel is a typical inactive metal which does not react with $\mathrm{Li}^{+}$at room temperature [54, 55]. However, $\mathrm{Ni}$ can react with $\mathrm{Si}$ to form metal silicide compounds. These compounds can then be used for the intercalation of $\mathrm{Li}^{+}$cations. Reaction mechanisms for this reaction have been proposed for the $\mathrm{Li}$ insertion and extraction in the Ni-Si alloy anode [20,21]:

$$
x \mathrm{Li}^{+}+x \mathrm{e}^{-}+\mathrm{NiSi} \rightarrow \mathrm{Li}_{x} \mathrm{Si}+\mathrm{Ni} \rightarrow \mathrm{Ni}+\mathrm{Si}+x \mathrm{Li}^{+}+x \mathrm{e}^{-} .
$$

In the proposed mechanisms, the theoretical specific capacity for NiSi is $1360 \mathrm{mAh} \mathrm{g}^{-1}$ if all the Si reacts with $\mathrm{Li}$ to form $\mathrm{Li}_{4.4} \mathrm{Si}$. It was believed that the element $\mathrm{Ni}$ formed during initial charge would act as buffering matrix to suppress the Si volume change [20]. Mechanical milling was firstly attempted to form $\mathrm{Ni}$-Si alloy anodes, and a homogenous NiSi phase was obtained. Although a high lithium storage capacity of $1180 \mathrm{mAh} \mathrm{g}^{-1}$ has been achieved in the initial discharge, the capacity faded rapidly, rendering the electrode unsuitable for batteries application [20]. A solution to this was proposed where a Si-rich $\mathrm{Ni}-\mathrm{Si}$ composite consisting of $\mathrm{Si}$ and $\mathrm{Si}_{2} \mathrm{Ni}$ was prepared by hydrogen plasma-metal reaction. For this $\mathrm{Si}-\mathrm{Ni}$ alloy, the Si-rich structure resulted in its high lithium storage capacity of $1304 \mathrm{mAh} \mathrm{g}^{-1}$, and the slower fading rate compared with pure $\mathrm{Si}$ anode could be attributed to the buffering of inert $\mathrm{Si}_{2} \mathrm{Ni}$ matrix [56]. Other than these structures of $\mathrm{Si}$ dispersed in inactive $\mathrm{NiSi}_{x}$ matrices, a Ni-Si composite in which Si nanoparticles are welded onto surfaces of metal particles by forming intermetallic interphases through a rapid heat treatment have also been researched [57]. The $\mathrm{Si} / \mathrm{Ni}$ composite synthesized at $900{ }^{\circ} \mathrm{C}$ delivered a capacity of $498 \mathrm{mAh} \mathrm{g}^{-1}$ at a current density of $233 \mathrm{~mA} \mathrm{~g}^{-1}$ and $73.7 \%$ of the capacity remained by the 100th cycle [37]. For this Ni-Si composite, the interparticle spacing could effectively accommodate the volume expansion of $\mathrm{Si}$, leading to improved cycling performance. Moreover, the electrochemically inactive intermetallic interphases in this composite serve as a special "glue" to prevent Si from losing electrical contact with binders and conductors. This synthesis concept can be employed to synthesize a variety of $\mathrm{Si} /$ metal composites, where the $\mathrm{Si}$ could be powders, wires, or films while the metal could be particles, wires, or foil-like substrates such as stainless steel.

In order to further improve the performance of $\mathrm{Ni}-\mathrm{Si}$ composite, various nanostructured $\mathrm{Ni}-\mathrm{Si}$ composites were synthesized using CVD [58-60]. Figure 5a illustrated a typical growth procedure of the $\mathrm{Si}-\mathrm{NiSi}_{x}$ nanocomposites
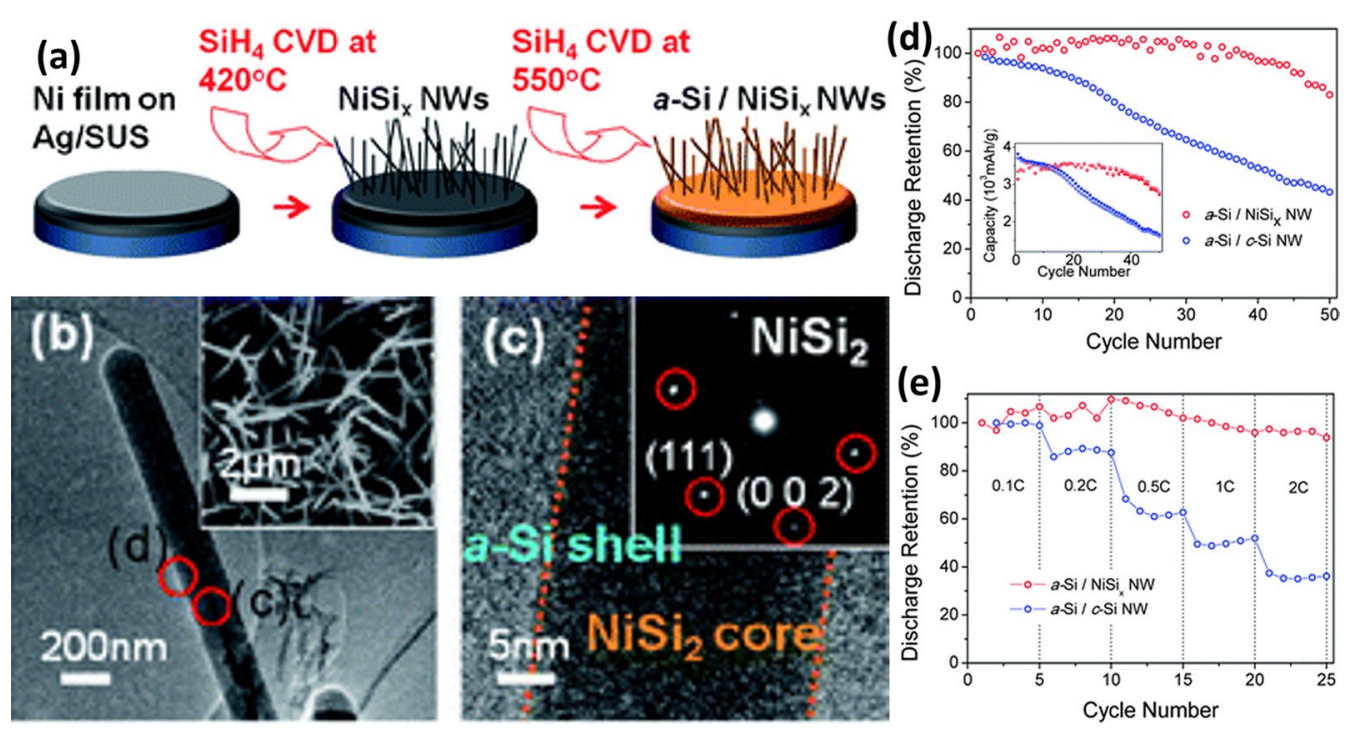

Fig. 5 a The schematic illustration for the growth process of the $\mathrm{Si}-\mathrm{NiSi}_{x}$ nanocomposites. $\mathbf{b}$ TEM image of an individual a-Si/NiSi ${ }_{x}$ nanowire. The inset shows a plan-view SEM image of a-Si/NiSi $i_{x}$ grown on substrate. c HRTEM image of an individual a-Si/NiSi $i_{x}$ nanowire at the core region and the corresponding electron diffraction pattern (inset). d The discharge capacity for the a-Si/NiSi ${ }_{x}$ nanowire and the a-Si/c-Si nanowire, respectively. e The rate capability for the a-Si/ $\mathrm{NiSi}_{x}$ nanowire and the a-Si/c-Si nanowire, respectively [59] 
by the CVD method [58]. According to the morphology characterization results in Fig. $5 \mathrm{~b}$, c, the $\mathrm{Si}-\mathrm{NiSi}_{x}$ nanocomposites are uniform nanowires composited of amorphous $\mathrm{Si}\left(\mathrm{a}-\mathrm{Si}\right.$ ) shell and $\mathrm{NiSi}_{2}$ core [58]. These a-Si/ $\mathrm{NiSi}_{x}$ core-shell nanowires exhibited a highly reversible capacity of over $3000 \mathrm{mAh} \mathrm{g}^{-1}$ even at a $2 \mathrm{C}$ rate, and almost $83 \%$ of the first discharge capacity was retained after the 50th cycle with high charge capacity above 3000 $\mathrm{mAh} \mathrm{g}^{-1}$ (Fig. 5d, e) [58]. Yang et al. [59] reported the $\mathrm{Ni}_{3} \mathrm{Si}_{2}$-supported $\mathrm{Si}\left(\mathrm{Ni}_{3} \mathrm{Si}_{2}-\mathrm{Si}\right)$ nanowires with a high reversible capacity of $\sim 1800$ and $\sim 1600 \mathrm{mAh} \mathrm{g}^{-1}$ at a high current rate of $1 \mathrm{C}$ and $2 \mathrm{C}$ during 100 cycles, respectively. Subsequently, they synthesized the vertically ordered $\mathrm{Ni}_{3} \mathrm{Si}_{2} /$ Si nanorod (NR) arrays on Ni foam, which showed good cycling performance and high capacity [60]. A high and steady discharge capacity of $2184 \mathrm{mAh} \mathrm{g}^{-1}$ and $1900 \mathrm{mAh}$ $\mathrm{g}^{-1}$ can be achieved after 50 cycles at $1 \mathrm{C}\left(4.2 \mathrm{~A} \mathrm{~g}^{-1}\right)$ and $2 \mathrm{C}\left(8.4 \mathrm{~A} \mathrm{~g}^{-1}\right)$, respectively [60]. These greatly improved performances could be attributed to the lower resistivity of nickel silicides and maintenance of good contacts with the current collector, and relatively small volume expansion routes in the core-shell nanowires prepared by accurate CVD method.

In addition to the CVD method, template-assisted electrochemical deposition was employed to prepare threedimensional Ni-Si nanocable arrays as high-performance anodes for lithium-ion batteries. The optimum composite nanocable array electrode achieves a high specific capacity of $1900 \mathrm{mAh} \mathrm{g}^{-1}$ at $0.05 \mathrm{C}$ [61]. The specific capacity remains at $1300 \mathrm{mAh} \mathrm{g}^{-1}$ (88\% of initial capacity) after 100 cycles at $0.5 \mathrm{C}$, suggesting good capacity retention ability. The high performance of the composite nanocable electrode is attributed to its excellent adhesion of the active material on the three-dimensional current collector and short ionic/ electronic transport pathways during cycling. Wang et al. reported a three-dimensional (3D) anode comprising a $\mathrm{Ni}$-coated Si microchannel plate (Si-MCP) as the matrix and active materials prepared by photo-assisted electrochemical etching and electroless deposition [62]. In this case, introduction of Ni coating turned out to have an obvious effect in improving the reversible capacity, but the number of cycles achieved is still not satisfactory for commercial battery applications.

2.1.2.2 Fe-Si The reaction mechanism of $\mathrm{Fe}$ in $\mathrm{Fe}-\mathrm{Si}$ alloy anode is the same as $\mathrm{Ni}$ in $\mathrm{Ni}-\mathrm{Si}$ :

$x \mathrm{Li}^{+}+x \mathrm{e}^{-}+\mathrm{FeSi} \rightarrow \mathrm{Li}_{x} \mathrm{Si}+\mathrm{Fe} \rightarrow \mathrm{Fe}+\mathrm{Si}+x \mathrm{Li}^{+}+x \mathrm{e}^{-}$.

After mechanically milling $\mathrm{Fe}$ with $\mathrm{Si}$, the product contained FeSi and Si phases and had a large particle size [21]. Although FeSi and NiSi alloy anodes have shown similar initial reversible capacities, NiSi composite showed better capacity retention compared to FeSi [21]. The poor cycle life of FeSi was due to the large particle size of the unalloyed $\mathrm{Si}$, which resulted in a large overall volume change.

To improve the electrochemical performance of $\mathrm{Fe}-\mathrm{Si}$ alloy, $\mathrm{Fe}-\mathrm{Si}$ alloy powders were annealed at $1000^{\circ} \mathrm{C}$ before milling [63]. From XRD analysis, the peaks of annealed alloys broaden with milling time and only $\alpha, \beta-\mathrm{FeSi}_{2}$ phase is detected [58]. It was hypothesized that the $\mathrm{Si}$ particles were embedded within the $\mathrm{FeSi}_{2}$ phase which can act as a stable buffering matrix to minimize volume change. Taking $\mathrm{Fe}_{27} \mathrm{Si}_{73}$ alloy as an example, its discharge capacity can be stable at $150 \mathrm{mAh} \mathrm{g}^{-1}$ [63]. However, Si-rich FeSi alloys $\left(\mathrm{Fe}_{20} \mathrm{Si}_{80}\right)$ deliver large initial capacity, but the capacity degrades rapidly with cycling. Poor cycling performance was attributed to the small amount of $\mathrm{FeSi}_{2}$ phase present in the anode, which could not completely cover all the $\mathrm{Si}$ particles [63]. In order to give full play to the advantages of initial coulomb efficiency and low cost of Fe-Si alloy, structure design is also used to further improve the energy density and cycle stability of active materials. He et al. [64] obtained a nanocrystal-FeSi-embedded $\mathrm{Si} / \mathrm{SiO}_{x}(\mathrm{FSO})$ anode by mechanical milling and heat treatment with $\mathrm{Fe}-\mathrm{Si}$ compounds which prepared by industry (Fig. 6a). The FSO anode exhibits excellent cycling stability with $84 \%$ capacity retention over 1000 cycles at $1 \mathrm{~A} \mathrm{~g}^{-1}$ (Fig. 6b). This satisfactory electrochemical performance is mainly due to the $\mathrm{SiO}_{x}$ shell was obtained by the oxidation of $\mathrm{Si}$ and the formation of solid FeSi core during the heat treatment, which inhibits the volume expansion and electrolyte corrosion during the cycles.

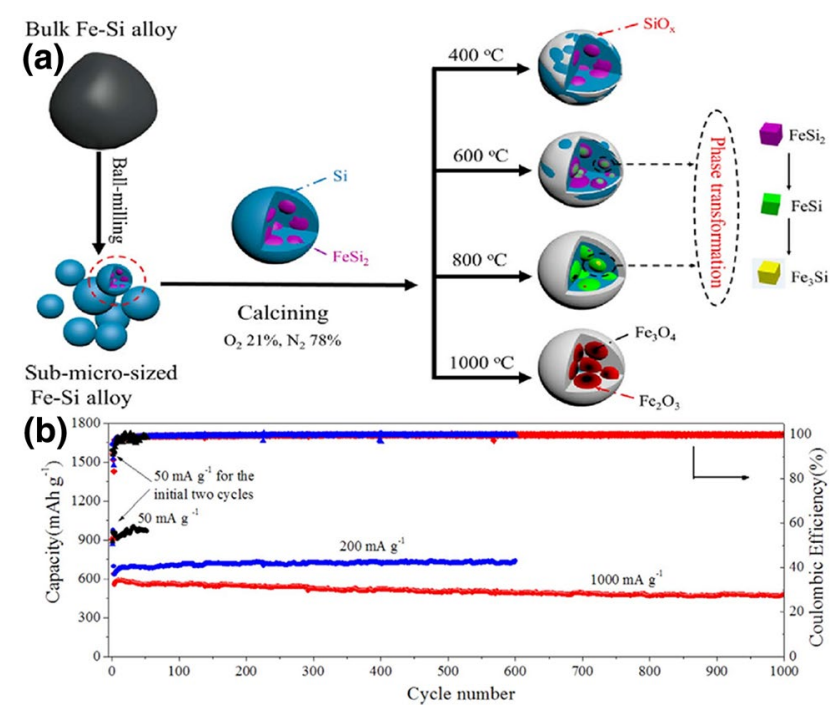

Fig. 6 a The schematic drawing of the ball milling and the calcining process for the preparation of FSO anode materials. b Cycling property of the $\mathrm{FSO}-800{ }^{\circ} \mathrm{C}$ electrode [64] 
2.1.2.3 Cu-Si Similar research was also conducted on $\mathrm{CuSi}$ alloy. Ball milling of $\mathrm{Cu}$ and $\mathrm{Si}$ powders produces $\mathrm{Cu}_{5} \mathrm{Si}$ alloy integrated with unalloyed silicon, followed by heat treatment of the milled sample at $600{ }^{\circ} \mathrm{C}$ [65]. However, the cycle capacity was drastically cut probably due to deactivation of more active silicon by alloying with copper and coating with inert $\mathrm{Cu}_{5} \mathrm{Si}$ alloy [65]. Unlike mechanically milled alloys, a $\mathrm{Cu}-\mathrm{Si}$ composite alloy was formed by electroless deposition of $\mathrm{Cu}$ on $\mathrm{Si}$ powders. To increase adhesion between $\mathrm{Cu}$ and $\mathrm{Si}, \mathrm{Cu}$ was deposited on etched $\mathrm{Si}$, followed by annealing at $400{ }^{\circ} \mathrm{C}$ [66]. The $\mathrm{Cu}$-coated $\mathrm{Si}$ powder showed higher electronic conductivity than the untreated material. However, its conductivity was reduced during annealing, which resulted in formation of resistive $\mathrm{Cu}_{3} \mathrm{Si}$ alloys [66]. When charged-discharged between 0.0 and $2.0 \mathrm{~V}$, the $\mathrm{Cu}$-coated $\mathrm{Si}$ electrode showed an unsatisfactory cycle life because of $\mathrm{Cu}$ detachment from the Si surface after just a few cycles, as was observed by SEM analysis [66]. As a good model to solve this problem, Prieto et al. [67] reported the in situ doping of $\mathrm{Si}$ nanowires with $\mathrm{Cu}$, which results in nanowires containing nanocrystalline inclusions of $\mathrm{Cu}_{3} \mathrm{Si}$ and significantly enhanced electrical conductivity. The electronic transport measurements conducted on single nanowires indicate that the electronic resistivity of the doped nanowires is several orders of magnitude lower than undoped Si. However, no galvanostatic cycling performance was reported for this anode [67]. Copper silicides can not only release the volume expansion in the process of charging and discharging, but also enhance the electronic conductivity. To further achieve high energy density, high power performance and excellent cycling stability, structural design is considered as a feasible approach. Song et al. [68] reported that highly connected hollow $\mathrm{Si}-\mathrm{Co}$ alloy mixture nanotubes without any binder which can easily realize the volume expansion inward instead of outward. Because of the existence of nanowire structure, the Si-Co alloys serve a high specific capacity of $780 \mathrm{mAh} \mathrm{g}^{-1}$, and high capacity retention performance of $88 \%$ after 1000 cycles. Song et al. [69] synthesized antipulverization and yet conductive $\mathrm{Cu}_{3} \mathrm{Si}$ embedded $\mathrm{Cu}-\mathrm{Si}$ NW hybrid anode by crossing-interconnected-hierarchicalhollow (Fig. 7). Upon the simple $\mathrm{H} 2$ annealing, the $\mathrm{CuO}$ is reduced to $\mathrm{Cu}$ and $\mathrm{Cu}$ diffused into $\mathrm{Si}$ alloy. Owing to this special structure, on the one hand, it can increase the load (a) Cu foam

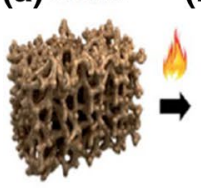

(b) CuO NW foam

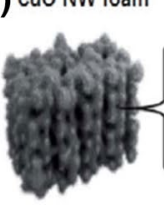

(g) $\mathrm{Al}_{2} \mathrm{O}_{3}$ coated hierarchical $\mathrm{Cu}-\mathrm{Si}$ hybrid structure

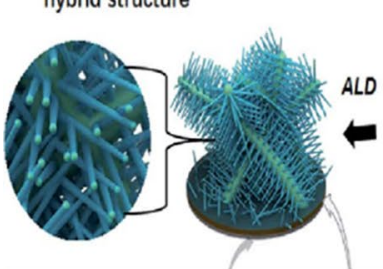

(f) Hierarchical Cu-Si hybrid structure

(c) Crossing CuO NWs

(d)Cu0@a-Si
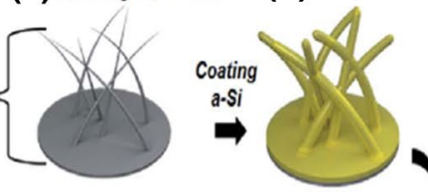

(e) Hierarchical c-Si/ CuO@a-Si structure
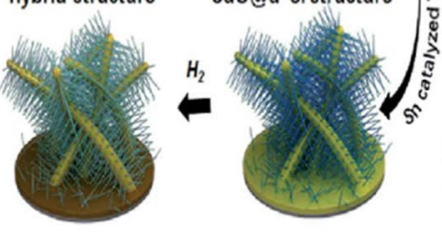

(h) The front and back plates of hierarchical Cu-Si hybrid structure

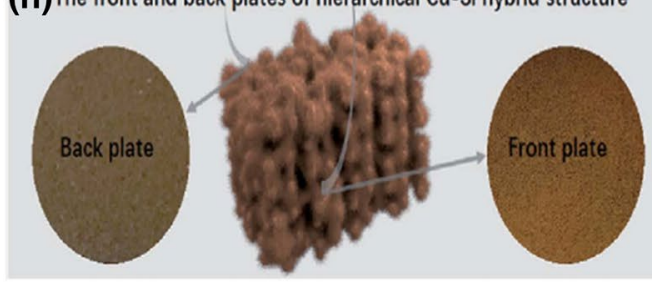

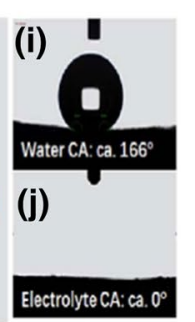
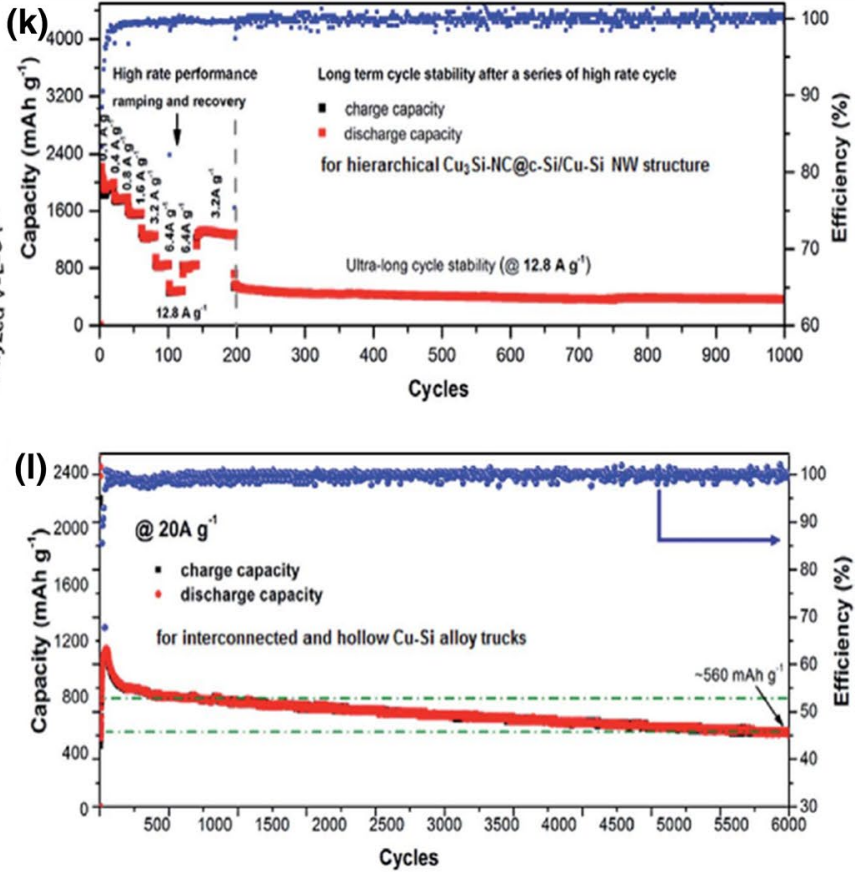

Fig. 7 Preparation process of the HCS NW structure grown overall on the copper foam substrate. A schematic illustration of the preparation of the HCS NW hybrid structure. a Copper foam. b and $\mathbf{c}$ Crossing $\mathrm{CuO}$ NWs grown on the CuO foam after thermal oxidation growth in atmosphere. d Interconnected $\mathrm{CuO} / \mathrm{a}-\mathrm{Si}$ core-shell NWs after coating the a-Si layer. e Sn-catalyzed Si NWs were grafted on the front and back plates of the $\mathrm{CuO} / \mathrm{a}-\mathrm{Si}$ core-shell NW foam, respectively, and finally obtained hierarchical nano-branched c-Si/CuO@a-Si core shell NW structures grown overall on the foam substrate in the PECVD system. $\mathbf{f}$ The hierarchical $\mathrm{Cu}-\mathrm{Si}$ NW hybrid structure grown on the copper foam after a high temperature $\mathrm{H}_{2}$ annealing process. $g$ ALD-coated ultra-thin $\mathrm{Al}_{2} \mathrm{O}_{3}$ on the hierarchical $\mathrm{Cu}-\mathrm{Si} \mathrm{NW}$ structure, and the corresponding image enlarged for detail. $\mathbf{h}$ Schematic diagram and photographs of the front and back plates of the HCS hybrid structure. i Photographs of a water droplet and $\mathbf{j}$ an electrolyte droplet on the surface of the HCS NW hybrid structure. $\mathbf{k}$ Cycling rate performance of the HCS NW hybrid anode with a mass loading of $1.2 \mathrm{mg} \mathrm{cm}^{-2}$. 1 Ultra-long-term cycling performance for ICS NT trunks (interconnected Cu-Si alloy nanotube trunks) at $20 \mathrm{~A} \mathrm{~g}^{-1}[69]$ 
of $\mathrm{Si}$ and inhibit the volume expansion, on the other hand, it can improve the electronic conductivity and mechanical support. A high specific capacity of $560 \mathrm{mAh} \mathrm{g}^{-1}$ has been achieved after 6000 cycles at $20 \mathrm{~A} \mathrm{~g}^{-1}$, with a satisfactory capacity retention rate of $70 \%$.

2.1.2.4 Ti-Si As a new anode material for lithium-ion batteries, titanium silicide has drawn much attention since it is lightweight, highly electrically conductive, and thermally stable [70]. Titanium silicides have been prepared either by ball milling the melt-spun ribbons or by mechanically alloying a mixture of element powder. The influence of the milling time on the electrochemical performance of these anodes in lithium-ion batteries has been investigated [71]. By optimizing the milling time, the best reversible capacity of $\mathrm{Ti}_{25} \mathrm{Si}_{75}$ melt-spun powders of $450 \mathrm{mAh} \mathrm{g}^{-1}$ after 50 cycles can be achieved [71].

Zhou et al. [72-75] reported unique two-dimensional C49 titanium disilicide ( $\mathrm{TiSi}_{2}$ nanonet) grown on $\mathrm{Ti}$ foil in a CVD reactor with $\mathrm{TiCl}_{4}$ and $\mathrm{SiH}_{4}$ as the precursors. Studies of the reaction mechanism with $\mathrm{Li}^{+}$reveal that the properties of $\mathrm{C} 49 \mathrm{TiSi}_{2}$ differ from ordinary $\mathrm{TiSi}_{2}$ drastically. C49 $\mathrm{TiSi}_{2}$ structure ( $\mathrm{TiSi}_{2}$ nanonet) is characterized by an orthorhombic unit cell where a Si-only layer appears every few atomic layers of mixed $\mathrm{Ti}$ and $\mathrm{Si}$, and the $\mathrm{Si}$-only layers serve as the host for high capacity (about $600 \mathrm{mAh} \mathrm{g}^{-1}$ ) (Fig. 8a) [72]. While ordinary $\mathrm{TiSi}_{2}$ structures without Si-only layers, such as C54 $\mathrm{TiSi}_{2}$ nanowires, exhibit low charge or discharge capacity $\left(<100 \mathrm{mAh} \mathrm{g}^{-1}\right)$ (Fig. 8b) [72]. In order to stabilize $\mathrm{TiSi}_{2}$ for improving performance and also rule out the possibility that the measured capacity is due to surface reactions, a thin $(<5 \mathrm{~nm})$ layer of oxide was coated on the surface of $\mathrm{TiSi}_{2}$ for analysis (Fig. 8c) [73]. Concomitantly, the $\mathrm{TiSi}_{2}$ nanonet can act as a good current collector because of its high surface area (ca. $100 \mathrm{~m}^{2} \mathrm{~g}^{-1}$ ), highly conductivity $\left(\sim 105 \mathrm{~S} \mathrm{~cm}^{-1}\right)$, and mechanical strength [73]. To achieve this the Si nanoparticles (approximately $20 \mathrm{~nm}$ dia.) are directly grown on the $\mathrm{TiSi}_{2}$ nanonets surfaces, synthesizing a unique heteronanostructure consisting of two-dimensional $\mathrm{TiSi}_{2}$ nanonets and particulate Si coating as the anode material for $\mathrm{Li}^{+}$storage (Fig. 8d) [74]. At a charge/discharge rate of $8400 \mathrm{~mA} \mathrm{~g}^{-1}$, specific capacities $>1000 \mathrm{mAh} \mathrm{g}^{-1}$ were measured. Only an average of $0.1 \%$ capacity fade per cycle was observed between the 20th and the 100th cycles (Fig. 8e) [74]. Similarly, a high-performance cathode is enabled by the $\mathrm{TiSi}_{2}-\mathrm{V}_{2} \mathrm{O}_{5}$ combination [75]. (a)

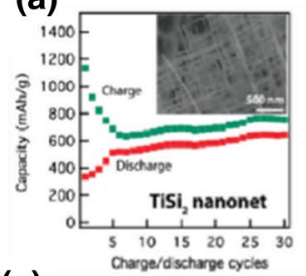

(c)

(b)
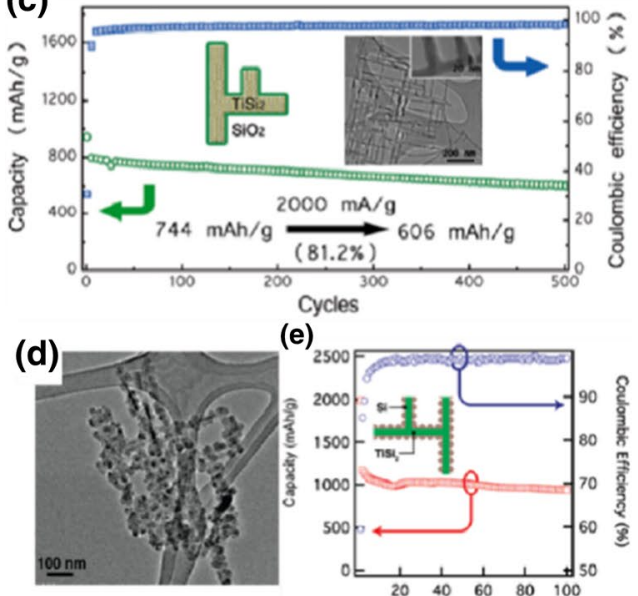

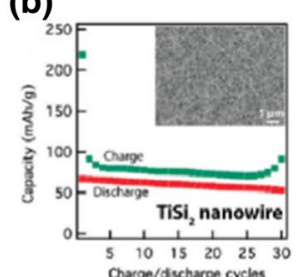

(e)

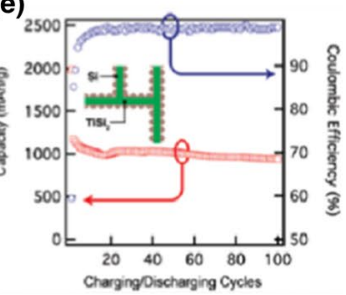

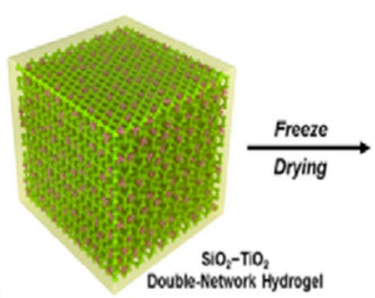

(f)

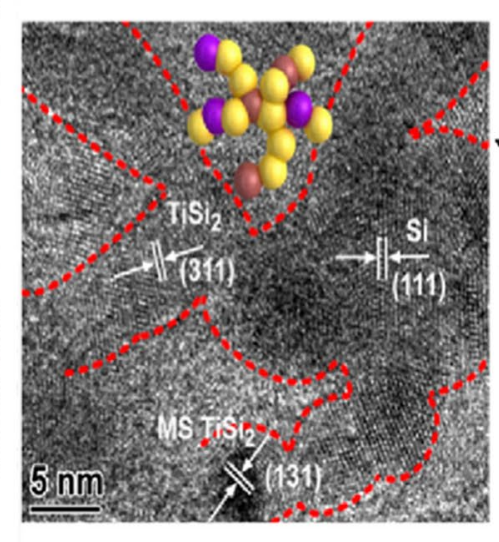

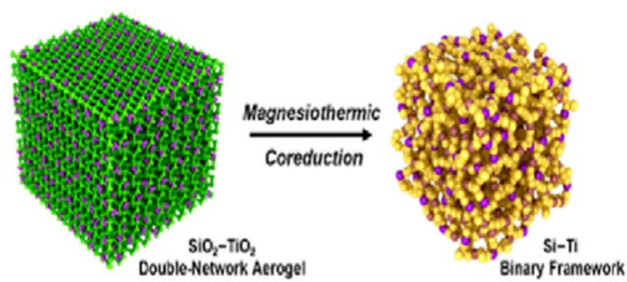

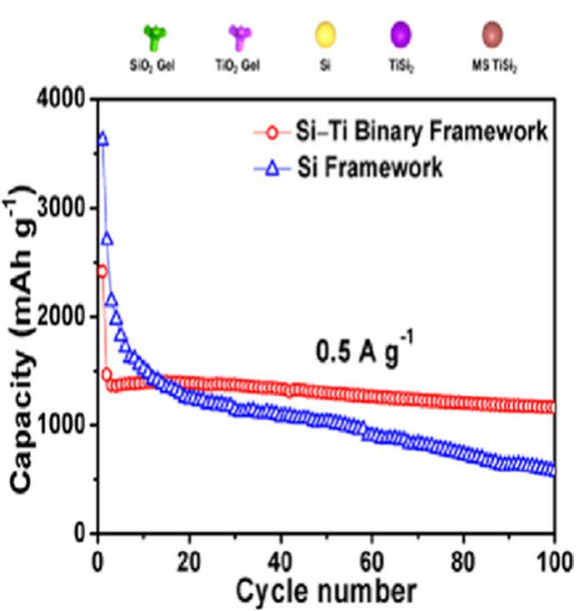

Fig. 8 a, b The capacities of $\mathrm{C} 49 \mathrm{TiSi}_{2}$ nanonets and ordinary $\mathrm{C} 54 \mathrm{TiSi}_{2}$ nanowires at a current density of $1000 \mathrm{~mA} \mathrm{~g}{ }^{-1}$, respectively. Insets: corresponding SEM pictures of the nanonets and nanowires, respectively. c Charge capacity and Coulombic efficiency of TiSi ${ }_{2}$ nanonets with oxide coating at a rate of $2000 \mathrm{~mA} \mathrm{~g}^{-1}$. Potential range: 1.0-0.01 V. Inset: Schematic and TEM images for clearly understand of TiSi ${ }_{2}$ nanonets with oxide coating. d A TEM picture manifests the particulate nature of the Si coating on $\mathrm{TiSi}_{2} \mathrm{NNs}$. e Charge capacity and Coulombic efficiency of the $\mathrm{Si} / \mathrm{TiSi}_{2}$ heteronanostructure at a rate of $8400 \mathrm{~mA} \mathrm{~g}{ }^{-1}$ tested between 0.150 and $3.00 \mathrm{~V}$. Inset: schematic of the $\mathrm{Si} / \mathrm{TiSi}_{2}$ heteronanostructure. $\mathbf{f}$ Structure of Si-Ti framework and its electrochemical performance $[72,75,77]$ 
Park et al. [70] synthesized $\mathrm{Ti}_{x} \mathrm{Si}_{y}$-coated $\mathrm{Si}$ anode via the silicothermic reduction process, in which the titanium silicide enhances the electrical conductivity of $\mathrm{Si}$ nanoparticles and forms the basis for a highly stable solid electrolyte interphase layer during the cycling. Therefore, $\mathrm{Ti}_{x} \mathrm{Si}_{y}$-coated $\mathrm{Si}$ electrodes exhibit excellent electrochemical performance, including a high specific capacity and good rate capability [62]. Similarly, micro-assembled Si-titanium silicides nanotube was synthesized using a magnesiothermic reduction reaction of $\mathrm{SiO}_{2}$-coated carbon nanotubes (CNTs) and $\mathrm{TiO}_{2} / \mathrm{SiO}_{2}$-coated CNTs [68]. The Si-based nanotube anodes exhibit a high capacity $\left(>1850 \mathrm{mAh} \mathrm{g}^{-1}\right)$ and an excellent cycling performance (capacity retention of $>99 \%$ after 80 cycles) [76]. Li et al. [77] prepared a $\mathrm{Si}-\mathrm{Ti}$ alloy with double framework which was fabricated on the basis of $\mathrm{SiO}_{2}-\mathrm{TiO}_{2}$ gel network, due to its excellent structure the prepared $\mathrm{Si}-\mathrm{Ti}$ alloy severs a good cycling stability at 0.5 $\mathrm{A} \mathrm{g}^{-1}$ and a high rate capacity (1190 $\mathrm{mAh} \mathrm{g}^{-1}$ at $\left.2 \mathrm{~A} \mathrm{~g}^{-1}\right)$.

2.1.2.5 Other $\mathrm{Mi}_{x} \mathrm{Si}_{y}$ Other transition metals such as Mn [78], Mo [79], W [80] and Cr [79] have also been investigated as a matrix to form alloys through mechanical milling. The electrochemical characteristics of $\mathrm{Si}-\mathrm{Mn}$ composites prepared by different ball milling times has been investigated [78]. A reversible capacity of $455 \mathrm{mAh} \mathrm{g}^{-1}$ and an initial Coulombic efficiency of $52 \%$ were obtained by $60 \mathrm{~h}$ ball milling followed by annealing at $300 \mathrm{C}$ for $2 \mathrm{~h}$ [78]. In Si-Mn composite electrodes, Mn can act as an inactive buffer for the active Si center and enhance cycling performance. However, the nanosized $\mathrm{Si}-\mathrm{Mn}$ particles tend to merge together after the insertion/extraction of lithium ions, which decreases electrical contact between the active materials and the underlying copper current collector [78]. $\mathrm{MoSi}_{2}$ and $\mathrm{CrSi}_{2}$ synthesized by high-energy ball milling of the corresponding metals have also been investigated as anode materials for Li-ion batteries [79]. According to the evolution of their crystalline phases determined through XRD studies [79], $20 \mathrm{~h}$ of ball milling was necessary for the formation of $\mathrm{MoSi}_{2}$ while $100 \mathrm{~h}$ for $\mathrm{CrSi}_{2}$. The prepared $\mathrm{MoSi}_{2}$ powders showed a capacity of about $125 \mathrm{mAh} \mathrm{g}^{-1}$ whereas $\mathrm{CrSi}_{2}$ powders provided a capacity of $340 \mathrm{mAh}$ $\mathrm{g}^{-1}$ at $\mathrm{C} / 12\left(1 \mathrm{C}=469 \mathrm{mAh} \mathrm{g}^{-1}\right)$ [79]. Both of the prepared powders have shown better battery performance than commercial powders.

\subsection{Ternary Metal Silicides}

In this section, we mainly discuss ternary metal silicides. These were typically fabricated by melt spinning rapid solidification process to obtain nanosized Si particles embedded within a matrix. The matrix can buffer the mechanical stresses generated during volume expansion

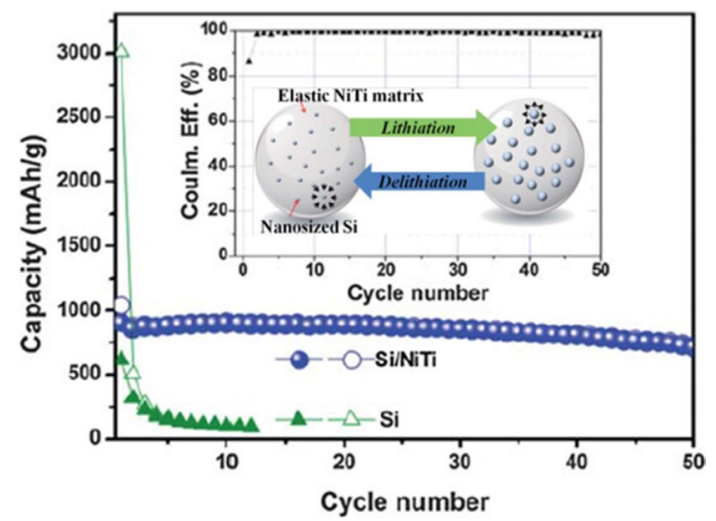

Fig. 9 Comparison of the cycle performances of the $\mathrm{Si} / \mathrm{NiTi}$ alloy and pure $\mathrm{Si}$ electrodes between 2.0 and $0.0 \mathrm{~V}\left(\mathrm{vs} . \mathrm{Li} / \mathrm{Li}^{+}\right)$at a cycling rate of $100 \mathrm{~mA} \mathrm{~g}^{-1}$ with coulombic efficiency. Inset: schematic microstructure of the $\mathrm{Si} / \mathrm{Ni}-\mathrm{Ti}$ matrix alloy [81]

and also provide good electrical contact with the current collector during lithiation and delithiation process. The characteristics of anode materials based on these materials for Li-ion batteries are dependent on the microstructure and the matrix phases, generated during rapid solidification. Thus, it is very important to explore suitable matrix phase compositions to evaluate the melt-spun alloys as candidates for anode materials.

\subsubsection{Si-Ti-Ni Metal Silicides}

$\mathrm{Si}-\mathrm{Ti}-\mathrm{Ni}$ ternary alloy system was a good choice for a high elastic strain matrix [81-84]. A nanosize $\mathrm{Si}$ embedded in super-elastic Nitinol alloy matrix composite was synthesized in large-scale using arc melting followed by rapid quenching [81]. Both XRD and high-resolution transmission electron microscope (TEM) with energydispersive spectroscopy analyses confirmed $\sim 50 \mathrm{~nm} \mathrm{Si}$ crystallites were surrounded by the Ni-Ti matrix [81]. This anode material showed a stable capacity of above $700 \mathrm{mAh} \mathrm{g}^{-1}$ after 50 cycles since the super-elastic Nitinol alloy matrix is able to withstand a deformation when a load is applied and return to the original shape when the load is removed, as shown in Fig. 9. Son et al. developed a $\mathrm{Si}-\mathrm{Ti}-\mathrm{Ni}$ ternary alloy where nano-Si particles were embedded in a $\mathrm{Ti}_{4} \mathrm{Ni}_{4} \mathrm{Si}_{7}$ matrix [82]. As an anode material for lithium-ion batteries, this alloy exhibits a stable capacity above $900 \mathrm{mAh} \mathrm{g}^{-1}$ after 50 cycles and a high columbic efficiency of up to $99.7 \%$ during cycling. In this case, after the first cycle, the matrix of $\mathrm{Ti}_{4} \mathrm{Ni}_{4} \mathrm{Si}_{7}$ is irreversible represented by $\mathrm{Li}_{x} \mathrm{Ti}_{4} \mathrm{Ni}_{4} \mathrm{Si}_{7}$ which results in faster and more efficient $\mathrm{Li}$ ion and electron transfer to nano-Si. The reduced formation of an SEI layer on the Si 
surface due to $\mathrm{Li}_{x} \mathrm{Ti}_{4} \mathrm{Ni}_{4} \mathrm{Si}_{7}$ matrix also contributes to the excellent performance.

Kwon et al [83] systematically investigated the electrochemical performance of various rapidly solidified $\mathrm{Si}-\mathrm{Ti}-\mathrm{Ni}$ alloys. Among the anode alloys, the $\mathrm{Si}_{70} \mathrm{Ti}_{15} \mathrm{Ni}_{15}$ electrodes had the highest discharge capacity $(974.1 \mathrm{mAh}$ $\mathrm{g}^{-1}$ ) after the 50th cycle. This research also revealed that the $\mathrm{Si}_{7} \mathrm{Ni}_{4} \mathrm{Ti}_{4}$ crystal phase coexisting with an amorphous phase, could more efficiently act as a buffer layer than the fully crystallized $\mathrm{Si}_{7} \mathrm{Ni}_{4} \mathrm{Ti}_{4}$ phase [83]. Ladam et al. [84] synthesized Si-rich $\mathrm{Ni}_{0.12} \mathrm{Ti}_{0.12} \mathrm{Si}_{0.76}$ by one-pot ball milling, which the specific capacity is of $700 \mathrm{mAh} \mathrm{g}^{-1}$ with a coulombic efficiency of $99.8 \%$ at the 50 cycles. Song et al. [85] researched the performance of nitrided Si-Ti-Ni (STN) ternary alloy prepared by the $\mathrm{NH}_{3}$ nitridation of STN alloy. The nitridated STN electrode shows $14 \%$ increased reversible capacity and 4 times higher rate capability at $3 \mathrm{C}$ compared to those of pristine STN electrode. These improvements are attributed to the formation of nitride compounds (such as $\mathrm{SiN}_{x} / \mathrm{SiN}_{x} \mathrm{O}_{y}$, $\mathrm{TiN}_{x} / \mathrm{TiN}_{x} \mathrm{O}_{y}$ and $\mathrm{NiN}_{x} / \mathrm{NiN}_{x} \mathrm{O}_{y}$ ) on STN alloy, which benefits both mechanic strength and kinetics [85].

\subsubsection{Si-Ti-Fe Metal Silicides}

The $\mathrm{Si}-\mathrm{Ti}-\mathrm{Fe}$ ternary alloy system has also begun to draw attention as a new anode material $[86,87]$. Because the co-melting of $\mathrm{Si}, \mathrm{Ti}$, and $\mathrm{Fe}$ evolves various ternary compounds with very high tensile strength and good electronic conductivity, these alloys seem to effectively

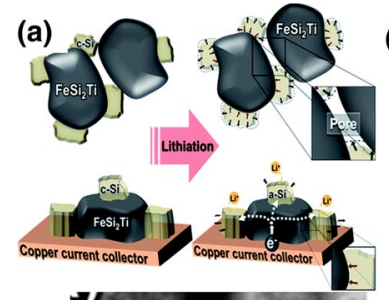

(b)
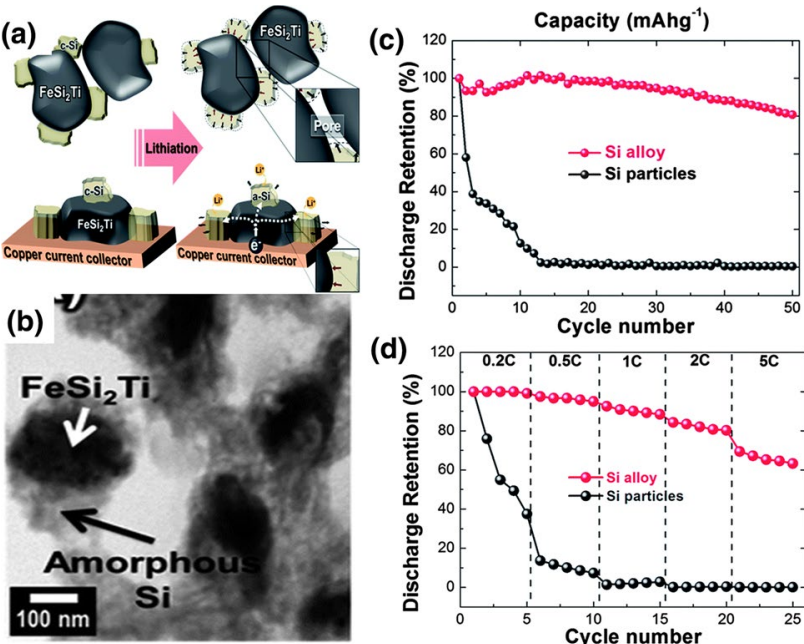

(d)

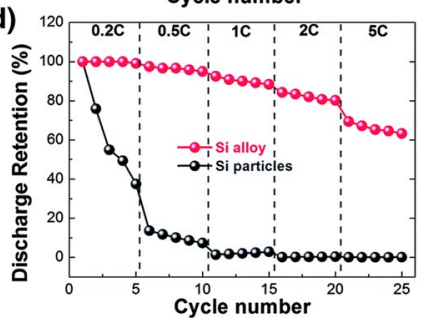

Fig. 10 a Schematic illustration of the nano- $\mathrm{Si} / \mathrm{FeSi}_{2} \mathrm{Ti}$ heterostructure during lithiation. b HRTEM images of the nano-Si/ $\mathrm{FeSi}_{2} \mathrm{Ti}$ heterostructure after 50 cycles. $\mathbf{c}$ The cyclic retention of the nano-Si/FeSi ${ }_{2} \mathrm{Ti}$ heterostructure and $\mathrm{Si}$ nanoparticles at $0.1 \mathrm{C}$. d The dependence of discharge retention on the variation of current density for galvanostatic charge-discharge [87] accommodate the mechanical stress and strain of $\mathrm{Si}$ and its lithium-bearing compounds, as well as contribute to maintaining good electronic contact between the active $\mathrm{Si}$ and the current collector during lithiation/delithiation [87]. Kim et al. [75] reported a $\mathrm{Si}-\mathrm{TiFeSi}_{2}$ composite synthesized by arc melting followed by rapid quenching and the composite showed a reversible capacity of $1200 \mathrm{mAh}$ $\mathrm{g}^{-1}$ over 50 cycles with a Coulombic efficiency of $89 \%$ for the first cycle. In this composite, nanosized cracks were observed only at the $\mathrm{Si}$ crystallites within the $\mathrm{Si}-\mathrm{TiFeSi}_{2}$ particles, indicating that the $\mathrm{TiFeSi}_{2}$ matrix was hard enough to withstand the stress generated during lithiation which explained the excellent capacity retention [86].

Another nano-Si/ $/ \mathrm{FeSi}_{2} \mathrm{Ti}$ heterostructure has been synthesized for highly reversible Li-ion batteries by using a simple melt-spinning method [87]. As shown in Fig. 10a, in this nano-Si/FeSi 2 Ti heterostructure, the $\mathrm{FeSi}_{2} \mathrm{Ti}$ matrix can serve as an efficient electron transport pathway, facilitating homogeneous lithiation into $\mathrm{Si}$, and also as a rigid mechanical support for Si domains in spite of their severe volume change. The pores surrounding its characteristic structure may be a second reason for the effective accommodation of the volume expansion of the $\mathrm{Si}$ domain during lithiation. Figure $10 \mathrm{~b}$ shows the well maintained nano-Si/FeSi ${ }_{2} \mathrm{Ti}$ composite after 50 cycles, verifying the continuous benefit of $\mathrm{FeSi}_{2} \mathrm{Ti}$ matrix during lithiation and delithiation. Hence, this nano- $\mathrm{Si} / \mathrm{FeSi}_{2} \mathrm{Ti}$ heterostructure anode exhibited a significant enhancement in capacity performance, cycling stability and rate capacity compared with an electrode comprising bare Si particles (Fig. 10c, d) [87].

\section{Metal Silicide/C Composites}

In the metal silicides/C composites, the inactive metal component serves as a buffer matrix, and the addition of carbon materials such as graphite and CNT enhances the connection and conductivity of anode materials. Park and co-workers reported a $\mathrm{Si}-\mathrm{Ni}$-carbon composite synthesized using high-energy mechanical milling for an anode in lithium-ion batteries and the $\mathrm{Si}-\mathrm{Ni}-\mathrm{Carbon}$ composite demonstrated a large reversible capacity of ca. $960 \mathrm{mAh} \mathrm{g}^{-1}$ with an excellent cycling stability [77]. The reason for good electrochemical characteristics is that uniformly dispersed $\mathrm{Ni}$ improved electronic conductivity and induced fast charge transport significantly in the $\mathrm{Si}-\mathrm{Ni}-\mathrm{Carbon}$ composite [88]. Lu et al. [89] synthesized a CNT-Ni-Si anode, demonstrating a high capacity over $2500 \mathrm{mAh} \mathrm{g}^{-1}$ and a low fading rate of merely $0.2 \%$ per cycle over 110 cycles. Introduction of the rough $\mathrm{Ni}$ interfacial layer and utilization of the CNT cores lead to reinforced stability of the structure, well accommodated stress and enhanced charge transfer, 
which are responsible for the improved performance [89]. In addition, pores and the disordered carbon layer played a role in accommodating the large volume change of $\mathrm{Si}$ during cycling. A composite comprising $\mathrm{Si}$ with a $\mathrm{Si} / \mathrm{Cu}$ core in a carbon shell was investigated as an anode material in lithium-ion batteries [90]. The $\mathrm{C} / \mathrm{Si}$ composite exhibits a reversible lithium storage capacity of $910 \mathrm{mAh} \mathrm{g}^{-1}$ and good cyclability, but the addition of $\mathrm{Cu}$ to the $\mathrm{Si}$ core in a carbon shell can further improve the cyclability of the composite, which reaches reversible capacity retention up to $94 \%$ after 20 cycles [90].

$\mathrm{Li}$ et al. [91] studied a $\mathrm{FeSi}_{6} /$ graphite composite in which the $\mathrm{FeSi}_{6}$ alloy particles consist of an electrochemically active silicon phase and inactive phase of $\mathrm{FeSi}_{2}$, distributed uniformly in the graphite matrix. Under the buffering effect of the inactive $\mathrm{FeSi}_{2}$ phase and graphite layers on the volumetric changes of $\mathrm{Si}$ phase during lithium-Si alloying reaction, the composite anode offers a large reversible capacity (about $800 \mathrm{mAh} \mathrm{g}^{-1}$ ) and good cyclability [91]. However, the contents of inactive metal component also affect the capacities of these composite anodes. In order to study the effect of $\mathrm{Ti}$ in the $\mathrm{Ti}-\mathrm{Si}-\mathrm{C}$ composite, various Ti-Si alloys $\left(\mathrm{Ti}_{14} \mathrm{Si}_{86}, \mathrm{Ti}_{16} \mathrm{Si}_{84}, \mathrm{Ti}_{21} \mathrm{Si}_{79}\right)$ were mixed with carbon for electrochemical tests [92]. For the $\mathrm{Ti}_{14} \mathrm{Si}_{86}$ alloy, containing primary $\mathrm{Si}$ and $\mathrm{Si}+\mathrm{TiSi}_{2}$ eutectic phases, the matrix is identified as the primary Si phase [92]. Therefore, the buffering action of $\mathrm{TiSi}_{2}$ phase in the $\mathrm{Ti}_{14} \mathrm{Si}_{86}$ alloy seems to be less effective than in the other Ti-Si alloys. It is likely that the pulverization of active alloy particles occurs more easily in the $\mathrm{Ti}_{14} \mathrm{Si}_{86}$ alloy compared to the $\mathrm{Ti}_{16} \mathrm{Si}_{84}$ and $\mathrm{Ti}_{21} \mathrm{Si}_{79}$ alloys, which leads to the inferior cyclability of the $\mathrm{Ti}_{14} \mathrm{Si}_{86}$-carbon composite electrode [92].

The $\mathrm{Cu}_{5} \mathrm{Si}-\mathrm{Si} / \mathrm{C}$ composites with different $\mathrm{Cu}$ content produced by high-energy ball milling of a mixture of copper-silicon alloy and graphite powder have been investigated [65]. $\mathrm{Cu}_{5} \mathrm{Si}-\mathrm{Si} / \mathrm{C}$ composite with $\mathrm{Si}: \mathrm{Cu}=1$ demonstrates an initial reversible capacity of $612 \mathrm{mAh}$ $\mathrm{g}^{-1}$ and the capacity retention is $74.5 \%$ at the 40 th cycle. However, increasing the amount of copper in the composites decreases reversible capacity but improves cycling performance.

Unlike inactive metals, the active metals may make a contribution to the anode capacity by reacting with $\mathrm{Li}^{+}$ [93-97]. Some of these active metals also serve as a buffer matrix which enhances the connection of anode, carbon and conductor. For mechanically ball-milled $\mathrm{Si}-\mathrm{Zn}-\mathrm{C}$ composite, the first charge and discharge capacities are approximately 852 and $607 \mathrm{mAh} \mathrm{g}^{-1}$, respectively, and that $91 \%$ of the initial discharge capacity of $607 \mathrm{mAh} \mathrm{g}^{-1}$ can be maintained for up to 40 cycles [93]. The superior cycling performance of the composite electrode is attributed to buffering of the mechanical stress generated during cycling and to improved electrical connection with the current collector afforded by the synergistic effect between $\mathrm{Li}_{2} \mathrm{ZnSi}$, $\mathrm{Zn}$ and graphite.

The $\mathrm{Sn}_{0.9} \mathrm{Si}_{0.1}$ core/carbon shell nanoparticles were synthesized from butyl-capped particles for high-density lithium storage materials [94]. These $\mathrm{Sn}_{0.9} \mathrm{Si}_{0.1}$ core/carbon shell nanoparticles exhibited excellent lithium storage ability at a high current, resulting in a value of $964 \mathrm{mAh} \mathrm{g}^{-1}$ at a rate of $0.3 \mathrm{C}\left(1 \mathrm{C}=1200 \mathrm{~mA} \mathrm{~g}^{-1}\right)$, and demonstrated good capacity retention after 50 cycles.

Zhou et al. [95] reported an Al-Si-graphite composite with low $7.9 \mathrm{wt} \%$ Si synthesized by ball milling eutectic Al-Si powder and graphite, for which the reversible capacity remained above $650 \mathrm{mAh} \mathrm{g}^{-1}$ after 10 cycles. In this case, addition of $7.9 \%$ silicon to an aluminum anode not only contributes to the total capacity but also improves the capacity retention. The $\mathrm{Si}$ also appears to form a superior surface layer in carbonate electrolytes that reduces the degradation of the bulk material.

A nanostructured $\mathrm{Ni}_{0.14} \mathrm{Sn}_{0.17} \mathrm{Si}_{0.32} \mathrm{Al}_{0.037} \mathrm{C}_{0.346}$ composite has been synthesized by mechanical milling of element $\mathrm{Si}, \mathrm{Al}$ and $\mathrm{C}$ graphite powders and $\mathrm{Ni}_{3.4} \mathrm{Sn}_{4}$ intermetallic precursor [96]. As a promising anode material for $\mathrm{Li}$-ion batteries, it shows a high reversible capacity reaching 920 $\mathrm{mAh} \mathrm{g}^{-1}$ with a good stability for 280 cycles [96]. The capacity is provided by lithiation of both $\mathrm{Si}$ and $\mathrm{Ni}_{3.4} \mathrm{Sn}_{4}$ phases, whereas the good stability is attributed to buffering of electrode volume variations by the $\mathrm{Ni}$ and $\mathrm{C}$ components.

Furthermore, the introduction of metal or metal silicides into Si-based anodes could improve the electrochemical property of anodes by optimizing their nanostructures. A novel layered zinc silicate/carbon composite was fabricated by embedding carbon into the interlayers of zinc silicate through a hydrothermal method [87]. The interlayer distance could be effectively tuned from 1.22 to $3.37 \mathrm{~nm}$ through the amount of carbon precursors, which has effects on the performance of the composite. Figure 11a shows the morphology of zinc silicate combined with moderately reduced graphene oxide. This composite can retain as high
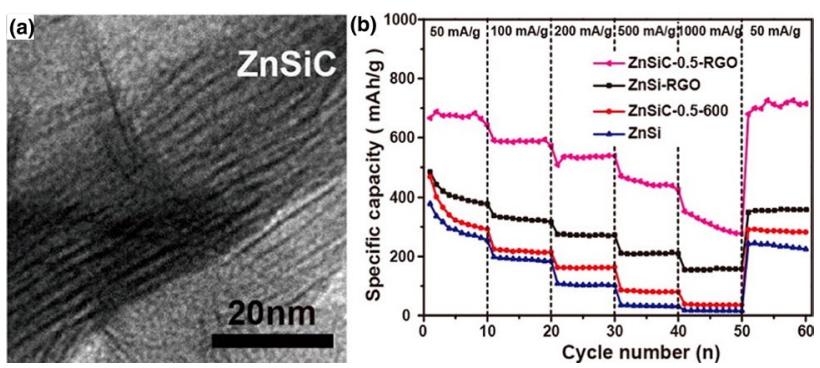

Fig. 11 a HRTEM image of the layered zinc silicate/C composited nanomaterials. b Reversible charge capacities of the above electrodes cycled at various rates $\left(50-1000 \mathrm{~mA} \mathrm{~g}^{-1}\right)$ [97] 
as $778 \mathrm{mAh} \mathrm{g}^{-1}$ at $50 \mathrm{~mA} \mathrm{~g}^{-1}$ after 50 cycles and exhibit good rate capacity (Fig. 11b) [97].

\section{Synthetic Methods of Metal Silicides}

Indeed, metal silicide anodes have been successfully prepared by various approaches such as ball milling [41, 84, 98], melt spinning, magnetron sputtering, chemical vapor deposition (CVD) methods. Among them, mechanical ball milling is considered to be one of the most attractive methods. Since it can produce nanosized and non-equilibrium phases nanocomponents such as nanocrystalline or amorphous powder, Ruttert et al. [98] prepared $\mathrm{Fe}_{x} \mathrm{Si}_{y}$ anode materials by controlling the milling time and Fe:Si ratio. In these alloys, nano-Si dispersed in intermetallic $\mathrm{FeSi}_{2}$ matrix as an inactive buffer phase displaying excellent cycling stability. Ladam et al. [84] synthesized Ni-Ti-Si composites by one-step ball milling, showing a specific capacity of $700 \mathrm{mAh} \mathrm{g}^{-1}$ with a coulombic efficiency of $99.8 \%$ at the 50th cycle. In addition to mechanical ball milling, CVD is another method to prepare metal silicides. Fukata et al. [99] synthesized $\mathrm{Si}-\mathrm{Fe}$ nanocomposite by CVD. First, nanogermanium was formed on stainless steel substrates by $\mathrm{GeH}_{4}$ at $300{ }^{\circ} \mathrm{C}$, and then $\mathrm{Si}$-based nanostructures were formed at $700{ }^{\circ} \mathrm{C}$ using $\mathrm{SiH}_{4}(100 \%)$ and $\mathrm{PH}_{3}(1 \%)$. In order to get more uniform nano-components, chemical reduction method is also used to prepare metal silicides, For example, Yao et al. [39] prepared $\mathrm{Si}$-Sn anode with $\mathrm{NaBH}_{4}$ as reducing agent, and $\mathrm{Li}$ et al. [77] synthesized $\mathrm{Si}-\mathrm{Ti}$ binary framework by reduction of $\mathrm{Mg}$ at $700{ }^{\circ} \mathrm{C}$ for $6 \mathrm{~h}$ under a $5 \% \mathrm{H}_{2} / \mathrm{Ar}$ atmosphere. While these metal silicides prepared by different methods can reduce volume change to a certain degree, it cannot completely eliminate volume expansion. Therefore, structure design is very important to alleviate the volume expansion, which often requires a good combination of multiple synthesis methods. Jia et al. [100] reported a facile synthesis for a porous core-shell $\mathrm{NiSi}_{2} / \mathrm{Si} / \mathrm{C}$ composite material. First, $\mathrm{NiSi}_{2} / \mathrm{Si}$ composite material was obtained by ball milling with $\mathrm{Li}, \mathrm{Ni}$ and $\mathrm{SiCl}_{4}$ as rough materials, then heated at $900{ }^{\circ} \mathrm{C}$ at $2 \mathrm{~h}$ in argon atmosphere. Furthermore, a CVD method is deployed to coat the $\mathrm{NiSi}_{2} / \mathrm{Si}$ phase with carbon. Usually the magnetron sputtering technique is often used to prepare high-performance metal silicides due to its ease of use and ability to produce large-scale uniform film. Zhang et al. [101] developed a composite anode of $\mathrm{Cu} / \mathrm{Si} / \mathrm{Ge}$ nanowire, which exhibited a stable capacity retention $(81 \%$ after 3000 cycles at 2C) and doubled specific capacity at rate of $16 \mathrm{C}$. The $\mathrm{Cu} / \mathrm{Si} / \mathrm{Ge}$ nanowires were fabricated by three steps. First, $\mathrm{CuO}$ was prepared on $\mathrm{Ni}$ foam by e-beam evaporation and furnace-heated, then $\mathrm{Si}$ and $\mathrm{Ge}$ were deposited on the surface of $\mathrm{CuO}$ nanowires by magnetron sputtering. Finally, the as-prepared $\mathrm{CuO} / \mathrm{Si} / \mathrm{Ge}$ nanowires were annealed at $300{ }^{\circ} \mathrm{C}$ in $\mathrm{H}_{2} / \mathrm{Ar}$ to transform $\mathrm{CuO} / \mathrm{Si} / \mathrm{Ge}$ nanowire arrays into $\mathrm{Cu} / \mathrm{Si} / \mathrm{Ge}$ nanowire arrays.

Table 2 Electrochemical performance of some metal silicides

\begin{tabular}{|c|c|c|c|c|}
\hline Materials & $\begin{array}{l}\text { Discharge plateaus } \\
\text { (V) }\end{array}$ & $\begin{array}{l}\text { Initial coulomb } \\
\text { efficiency }(\%)\end{array}$ & $\begin{array}{l}\text { Cycling stability (current rate, specific capacity, cycle } \\
\text { numbers, capacity retention) }\end{array}$ & References \\
\hline $\mathrm{Mg}_{2} \mathrm{Si}$ & $0.01-3.0$ & 84.0 & $100 \mathrm{mAh} \mathrm{g}^{-1}, 1040 \mathrm{mAh} \mathrm{g}^{-1}, 35$ cycles, $4.0 \%$ & [26] \\
\hline $\mathrm{Mg}_{2} \mathrm{Si} / \mathrm{C}$ & $0.02-2.0$ & 60.6 & $100 \mathrm{mAh} \mathrm{g}^{-1}, 1199 \mathrm{mAh} \mathrm{g}^{-1}, 500$ cycles, $39.2 \%$ & {$[28]$} \\
\hline $\mathrm{Ge}_{0.1} \mathrm{Si}_{0.9}$ & $0.02-2.0$ & 94.0 & $0.8 \mathrm{~mA} \mathrm{~g}^{-1}, 2022.12 \mathrm{mAh} \mathrm{g}^{-1}, 100$ cycles, $52.8 \%$ & {$[30]$} \\
\hline $\mathrm{Ge}_{0.25} \mathrm{Si}_{0.75}$ & $0.02-2.0$ & 95.0 & $0.8 \mathrm{~mA} \mathrm{~g}^{-1}, 1992.10 \mathrm{mAh} \mathrm{g}^{-1}, 100$ cycles, $62.8 \%$ & [30] \\
\hline $\mathrm{Ge}_{0.5} \mathrm{Si}_{0.5}$ & $0.02-2.0$ & 98.0 & $0.8 \mathrm{~mA} \mathrm{~g}^{-1}, 1934.12 \mathrm{~mA} \mathrm{~g}^{-1}, 100$ cycles, $64.3 \%$ & {$[30]$} \\
\hline $\mathrm{Si} / \mathrm{Ag} / \mathrm{C}$ & $0.005-3.0$ & 61.9 & $200 \mathrm{mAh} \mathrm{g}^{-1}, 988 \mathrm{mAh} \mathrm{g}^{-1}, 10$ cycles, $71.0 \%$ & [102] \\
\hline $\mathrm{Si} / \mathrm{Ni}$ & $0.0-2.0$ & 82.4 & $233 \mathrm{~mA} \mathrm{~g}^{-1}, 650 \mathrm{mAh} \mathrm{g}^{-1}, 100$ cycles, $72.9 \%$ & [57] \\
\hline $\mathrm{Si}_{80} \mathrm{Ni}_{20}$ & $0.0-2.0$ & 59.0 & $50 \mathrm{mAh} \mathrm{g}^{-1}, 1304 \mathrm{mAh} \mathrm{g}^{-1}, 15$ cycles, $7.7 \%$ & {$[56]$} \\
\hline $\mathrm{Si}_{70} \mathrm{Ni}_{30}$ & $0.005-2.0$ & 80.9 & $240 \mathrm{mAh} \mathrm{g}^{-1}, 600 \mathrm{mAh} \mathrm{g}^{-1}, 30$ cycles, $90 \%$ & {$[103]$} \\
\hline $\mathrm{NiSi}_{2} / \mathrm{Si} / \mathrm{C}$ & $0.01-1.1$ & 81.0 & 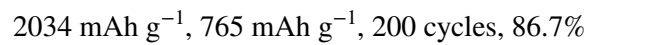 & [100] \\
\hline $\mathrm{MP}-\mathrm{Si} / \mathrm{Ni} / \mathrm{C}$ & $0.01-1.5$ & 68.2 & $200 \mathrm{mAh} \mathrm{g}^{-1}, 1942.4 \mathrm{mAh} \mathrm{g}^{-1}, 120$ cycles, $57.3 \%$ & [104] \\
\hline $\mathrm{Fe}_{14} \mathrm{Si}_{86}$ & $0.02-1.5$ & 92.0 & $100 \mathrm{mAh} \mathrm{g}^{-1}, 1528 \mathrm{mAh} \mathrm{g}^{-1}, 100$ cycles, $34.8 \%$ & [98] \\
\hline $\mathrm{Fe}_{10} \mathrm{Si}_{90}-\mathrm{G}-\mathrm{C}$ & $0.0-2.0$ & 87.0 & $200 \mathrm{mAh} \mathrm{g}^{-1}, 1201 \mathrm{mAh} \mathrm{g}^{-1}, 80$ cycles, $88.5 \%$ & [105] \\
\hline $\mathrm{Fe}_{20} \mathrm{Si}_{40}-\mathrm{G}$ & $0.0-1.2$ & 84.0 & $-, 800 \mathrm{mAh} \mathrm{g}^{-1}, 20$ cycles, $75.0 \%$ & {$[63]$} \\
\hline $\mathrm{Si}-\mathrm{Cu}_{3} \mathrm{Si}$ & $0.0-1.5$ & 93.5 & $100 \mathrm{mAh} \mathrm{g}^{-1}, 1310 \mathrm{mAh} \mathrm{g}^{-1}, 30$ cycles, $83.0 \%$ & [106] \\
\hline $\mathrm{Si}-\mathrm{Ti}$ & $0.02-1.5$ & 77 & $0.1 \mathrm{~mA} \mathrm{~cm}^{-3}, 1542 \mathrm{mAh} \mathrm{g}^{-1}, 50$ cycles, $15.3 \%$ & [107] \\
\hline $\mathrm{Si}-\mathrm{Mn} / \mathrm{rGO}$ & $0.01-3.25$ & 64.6 & $100 \mathrm{mAh} \mathrm{g}^{-1}, 1033 \mathrm{mAh} \mathrm{g}^{-1}, 50$ cycles, $57.6 \%$ & [108] \\
\hline $\mathrm{Si} / \mathrm{Co}-\mathrm{CoSi}_{2}$ & $0.01-3.0$ & 77.9 & $100 \mathrm{mAh} \mathrm{g}^{-1}, 1200 \mathrm{mAh} \mathrm{g}^{-1}, 80$ cycles, $79.3 \%$ & [109] \\
\hline
\end{tabular}




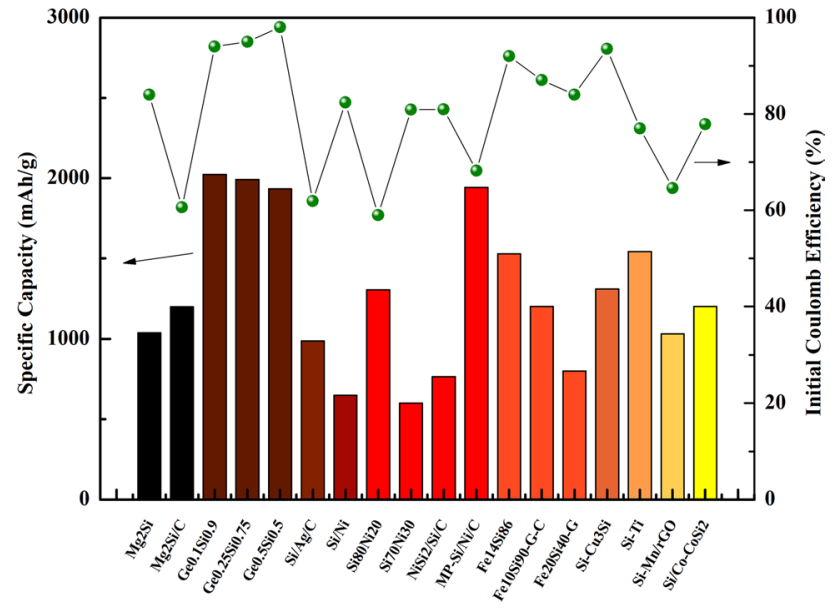

Fig. 12 Electrochemical performance of some metal silicides

\section{Comparative Analysis of Metal Silicides}

In the past 20 years, a large of number metal silicides have been explored as anode materials for lithium-ion batteries, and their insertion/extraction mechanisms of lithium have been reported in the literature. Generally, in the presence of Li-active metal in the M-Si alloy anodes, an obvious decrease in capacity retention was observed in spite of high initial capacities. This is due to the increase in the pulverization of the anodes resulting from $\mathrm{Li}$ insertion into the active metal matrix. By comparison, the anodes of metal silicides containing Li-inactive metals usually give rise to lower reversible capacity since the inactive host matrix does not involve electrochemical reaction except for the low content Si-active material. But the inactive matrix present in such type of metal silicides can sustain the $\mathrm{Si}$ volume changes during the lithiation and delithiation process, which results in a good cycling stability.

Since the types of metal silicides and their composite materials and number of alloy compositions tested are large, the electrochemical data obtained from literature were tabulated (see Table 2) to determine material showing superior electrochemical performance. In order to facilitate comparisons, we drew a chart showing the specific capacity and initial coulombic efficiency of some metal silicide and their carbon composites, as shown in Fig. 12. It can be seen from Fig. 12 and Table 2 that the Li-active metals ( $\mathrm{Mg}, \mathrm{Ge}, \mathrm{Ca}, \mathrm{Ag}$ ) have higher specific capacity but poorer cycling stability. For the Li-inactive metals $(\mathrm{Ni}, \mathrm{Fe}, \mathrm{Cu}, \mathrm{Ti})$, high specific capacity can be achieved at low operating voltage by adjusting the content of $\mathrm{Si}$ in the inactive matrix. Moreover, the capacity retention can be improved with the help of graphite addition and carbon coating. From the comparative analysis, the metals of Ge, $\mathrm{Mg}, \mathrm{Ni}, \mathrm{Fe}, \mathrm{Cu}$, Ti forming silicides are expected to be

Table 3 Electrochemical performance of different nanostructured metal silicides

\begin{tabular}{|c|c|c|c|c|c|c|}
\hline Type of silicide & Nanostructure & Capacity $\left(\mathrm{mAh} \mathrm{g}^{-1}\right)$ & Cycle & $\begin{array}{l}\text { Capacity } \\
\text { retention } \\
(\%)\end{array}$ & Current density & References \\
\hline $\mathrm{Si}_{0.5} \mathrm{Ge}_{0.5}$ & Mixed particles & 2022.12 & 100 & 64.3 & $0.8 \mathrm{~mA} \mathrm{~g}^{-1}$ & {$[30]$} \\
\hline $\mathrm{Si} / \mathrm{Ge}$ & Nanotube & 2362 & 100 & 24.8 & $200 \mathrm{mAh} \mathrm{g}^{-1}$ & [110] \\
\hline $\begin{array}{l}\text { cpSG@C (canyon-like Si-Ge } \\
\text { alloy@C) }\end{array}$ & $\begin{array}{l}\text { Nanoparticles with canyon-like } \\
\text { surface }\end{array}$ & 1247 & 100 & 78.3 & $500 \mathrm{mAh} \mathrm{g}^{-1}$ & [111] \\
\hline $\mathrm{Si}_{53} \mathrm{Ge}_{47}$ & Core-shell & 1692 & 60 & 90.0 & $5 \mathrm{C}$ & {$[112]$} \\
\hline $\mathrm{Si}_{0.67} \mathrm{Ge}_{0.33}$ & Nanowires & 1709 & 250 & 79.6 & $\mathrm{C} / 5$ & {$[32]$} \\
\hline $\mathrm{Si} / \mathrm{Ge}$ & Heterostructure nanowires & 1644 & 400 & 71.8 & $\mathrm{C} / 5$ & {$[33]$} \\
\hline $\mathrm{Ni}_{3} \mathrm{Si} / \mathrm{Si} / \mathrm{NWs}$ & Core-shell & 3773 & 50 & 71.0 & $2.1 \mathrm{~A} \mathrm{~g}^{-1}$ & [113] \\
\hline $\mathrm{Ni}_{x} \mathrm{Si}_{y}$ & Core-shell nanowire & 1406 & 100 & 73.7 & $1 \mathrm{~A} \mathrm{~g}^{-1}$ & [114] \\
\hline $\mathrm{NiSi}_{x} / \mathrm{a}-\mathrm{Si}$ & Nanowire & 1400 & 150 & 87.3 & $10 \mathrm{Ag}^{-1}$ & {$[115]$} \\
\hline $\mathrm{Ni} / \mathrm{Si}$ & Core/shell nanosheet & 2905 & 100 & 87.0 & $\mathrm{C} / 2$ & [116] \\
\hline $\mathrm{Ni}_{2} \mathrm{Si} / \mathrm{Si}$ & Core-shell & 1547 & 600 & 85.0 & $358 \mathrm{~mA} \mathrm{~g}^{-1}$ & [117] \\
\hline $\begin{array}{l}\text { 3DGF/Cu/Si (three-dimensional } \\
\text { graphene foam } / \mathrm{Cu} / \mathrm{Si} \text { ) }\end{array}$ & Core-shell nanoflowers & 1647 & 500 & 65.1 & $3.2 \mathrm{~A} \mathrm{~g}^{-1}$ & [118] \\
\hline $\mathrm{Si}-\mathrm{Cu}$ & Nanotubes & 780 & 1000 & 88.0 & $20 \mathrm{~A} \mathrm{~g}^{-1}$ & {$[68]$} \\
\hline $\mathrm{Cu}-\mathrm{Si}$ & Core-shell nanotube arrays & 2473 & 400 & 60.9 & $\mathrm{C} / 2$ & [119] \\
\hline $\begin{array}{l}\mathrm{HCS} N W \text { (hierarchical } \mathrm{Cu}-\mathrm{Si} \\
\text { nanowire) }\end{array}$ & Nanowire hybrids & 800 & 9000 & 60.0 & $20 \mathrm{~A} \mathrm{~g}^{-1}$ & {$[69]$} \\
\hline $\mathrm{Si}_{80} \mathrm{Ti}_{20}$ & Thin film & 1017 & 300 & $\approx 100$ & $2 \mathrm{~A} \mathrm{~g}^{-1}$ & {$[120]$} \\
\hline $\mathrm{Si}-\mathrm{Ti}$ & Binary framework & $960(2 \mathrm{nd})$ & 200 & 82.1 & $2 \mathrm{~A} \mathrm{~g}^{-1}$ & [77] \\
\hline
\end{tabular}




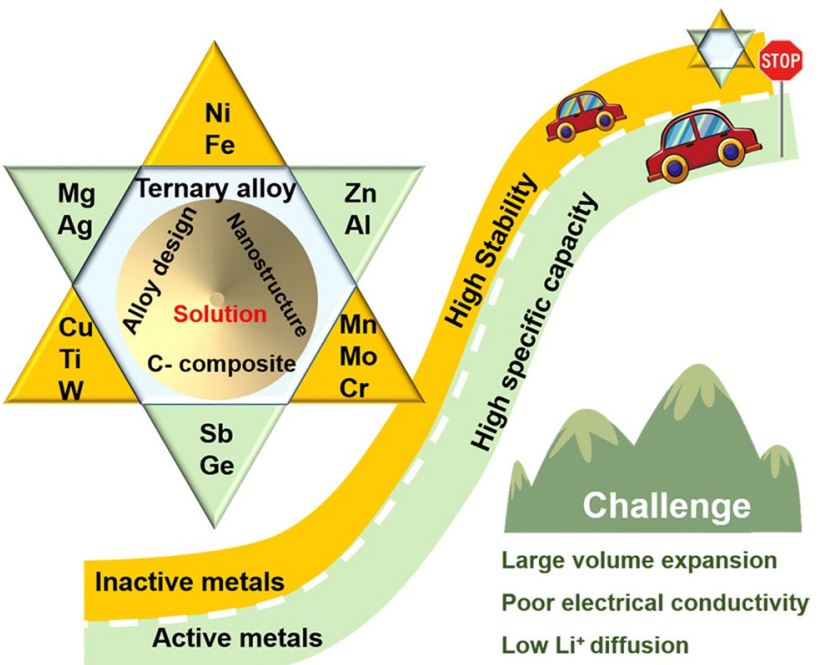

Fig. 13 Schema of a classification of metal silicides, corresponding challenges and solutions

the potential anode materials for Li-ion batteries. Besides, the initial coulombic efficiency (ICE) is a very important parameter to evaluate the performance of metal silicide anodes. From the dotted polyline of Fig. 12, the metal silicides containing $\mathrm{Ge}, \mathrm{Fe}, \mathrm{Cu}, \mathrm{Ti}$, particularly $\mathrm{Si}-\mathrm{Ge}$ solid solution, exhibit a better initial coulombic efficiency. This indicates that more active $\mathrm{Li}$ can return to the cathode in a fully discharged state, and hopefully achieve a high energy density required for practical LIBs.

Although the metal silicides ( $\mathrm{Ge}-\mathrm{Si}, \mathrm{Ni}-\mathrm{Si}, \mathrm{Fe}-\mathrm{Si}, \mathrm{Cu}-\mathrm{Si}$ and $\mathrm{Ti}-\mathrm{Si}$ alloy) have relatively high ICE and noticeable reversible capacity, their cycling stability is still unsuitable for commercial application. To further improve cycling performance, the integration of carbon and nanostructure to metal silicides is considered as an important combinatorial strategy. When carbon or graphite was added into a metal-silicide composite anode, a significant improvement in capacity retention has been reported. This is due to the compliant nature of carbon, which maintains contact and stability of the composite anodes during the volume changes, at least to a certain extent. Carbon and metal component permit formation of a conductive network outside and inside the anode particles, which resulted in improved electronic connection. The nanostructured approach to overcome poor stability is the design and synthesis of complex nanostructure which can not only release the volume expansion in the process of charging and discharging, but also enhance the conductivity of $\mathrm{Li}$ ion. The electrochemical performance of different nanostructured metal silicides were summarized in Table 3. It can be seen that most of the nanostructural design can significantly improve cycling stability and rate performance. However, the large-scale and cost-effective nanostructured processing will face the challenge for metal silicide production in the future.

\section{Summary and Perspectives}

In summary, the combination of Si with a variety of different metals can form a large number of metal silicides. Basically these can be classified into two types: Li-active metal forming silicides and Li-inactive metal forming silicides, as shown in Fig. 13.

For the Li-active metal forming silicides, they can provide a high capacity due to the combined contribution of $\mathrm{Si}$ and the active metals like $\mathrm{Sn}, \mathrm{Ag}, \mathrm{Zn}$ and $\mathrm{Al}$ allowing Li reversible insertion/extraction, but cannot sustain large volume changes, and thus have poor capacity retention during cycling. As for the Li-inactive metal forming silicides, the size of initial capacity depends on the content of Si dispersed either in the inactive elemental state matrix (such as $\mathrm{Ni}, \mathrm{Fe}$ and $\mathrm{Cu}$ ) or in the inactive intermetallic compound matrix (such as $\mathrm{NiSi}_{2}, \mathrm{CoSi}_{2}$ and $\mathrm{FeSi}_{2}$ ). This type of metal-silicides has relatively good cycling performance due to the ability of the inactive phase to accommodate the $\mathrm{Si}$ volume changes. No matter what types, the combination of metal silicides with carbon can form a composite structure and further improve the capacity retention ability.

In the future, more effort should be put into excellent strategies for improving the electrochemical properties of metal silicide anodes toward the practical Li-ion batteries. One strategy is to create a composite structure consisting of high-strength inactive phases in order to withstand the volume change of $\mathrm{Si}$ on cycling through alloy composition design of multi-component metal silicides. Ideally, the inactive matrix phases have high electronic conductivity to allow charge transfer reaction occurring in the alloy anodes. Reducing Si particle size to nanoscale is still very important strategy for particular improvement in electrochemical performance. When nanoscale $\mathrm{Si}$ is dispersed in the inactive matrix, the metal-silicide anodes are usually amenable to obtaining high initial capacity and stable cyclability. Another strategy is to prepare carbon-containing metal-silicide composite anodes by adding carbon-based materials such as graphite, nano-carbon into the $\mathrm{Si}$-active/inactive metal matrix in order to improve electronic conductivity and rate capacity.

Acknowledgements This work is financially supported by the SchoolEnterprise cooperation Project (RD18200058), the Anhui Natural Science Foundation (No. 1908085ME151), the Anhui province high-end talent Grant (DT18100044), the Key Laboratory of Marine Materials and Related Technologies, CAS (2019K07) and the National Foreign Expert Introduction Plan Project (G20190219004). 


\section{References}

[[1] M. Armand, J.M. Tarascon, Nature 451, 652 (2008)

[2] J.M. Tarascon, M. Armand, Nature 414, 359 (2001)

[3] B. Kang, G. Ceder, Nature 458, 190 (2009)

[4] N.S. Choi, Z. Chen, S.A. Freunberger, X. Ji, Y.K. Sun, K. Amine, G. Yushin, L.F. Nazar, J. Cho, P.G. Bruce, Angew. Chem. Int. Ed. 51, 9994 (2012)

[5] A.S. Aricò, P. Bruce, B. Scrosati, J.M. Tarascon, W. van Schalkwijk, Nat. Mater. 4, 366 (2005)

[6] D. Larcher, S. Beattie, M. Morcrette, K. Edström, J.C. Jumas, J.M. Tarascon, J. Mater. Chem. 17, 3759 (2007)

[7] Z. Cai, Y. Ma, X. Huang, X. Yan, Z. Yu, S. Zhang, G. Song, Y. Xu, C. Wen, W. Yang, J. Energy Storage 27, 101036 (2020)

[8] M.S. Whittingham, Chem. Rev. 104, 4271 (2004)

[9] U. Kasavajjula, C. Wang, A.J. Appleby, J. Power Sources 163, 1003 (2007)

[10] G. Venugopal, J. Moore, J. Howard, S. Pendalwar, J. Power Sources 77, 34 (1999)

[11] F. Croce, G.B. Appetecchi, L. Persi, B. Scrosati, Nature 394, 456 (1998)

[12] B.A. Boukamp, G.C. Lesh, R.A. Huggins, J.E. Soc, J. Electrochem. Soc. 128, 725 (1981)

[13] W.R. Liu, Z.Z. Guo, W.S. Young, D.T. Shieh, H.C. Wu, M.H. Yang, N.L. Wu, J. Power Sources 140, 139 (2005)

[14] H.S. Kim, K.Y. Chung, B.W. Cho, J. Power Sources 189, 108 (2009)

[15] C.J. Wen, R.A. Huggins, J. Solid State Chem. 37, 271 (1981)

[16] D.L. Fang, Y.C. Zhao, S.S. Wang, T.S. Hu, C.H. Zheng, Electrochim. Acta 330, 135346 (2020)

[17] W. Li, Y. Tang, W. Kang, Z. Zhang, X. Yang, Y. Zhu, W. Zhang, C.S. Lee, Small 11, 1345 (2015)

[18] D. Bo, H. Xuanning, C. Zhenfei, M. Yangzhou, S. Guangsheng, Y. Weidong, W. Cuie, Inorg. Chem. Commun. 113, 107771 (2020)

[19] H. Kim, J. Choi, H.J. Sohn, T. Kang, J. Electrochem. Soc. 146, 4401 (1999)

[20] G.X. Wang, L. Sun, D.H. Bradhurst, S. Zhong, S.X. Dou, H.K. Liu, J. Power Sources 88, 278 (2000)

[21] G.X. Wang, L. Sun, D.H. Bradhurst, S. Zhong, S.X. Dou, H.K. Liu, J. Alloys Compd. 306, 249 (2000)

[22] G.A. Roberts, E.J. Cairns, J.A. Reimer, J. Electrochem. Soc. 151, A493 (2004)

[23] J. Wolfenstine, J. Power Sources 124, 241 (2003)

[24] J.M. Yan, H.Z. Huang, J. Zhang, Y. Yang, J. Power Sources 175, 547 (2008)

[25] G.A. Roberts, E.J. Cairns, J.A. Reimer, J. Power Sources 110, $424(2002)$

[26] Y. Liu, Y. He, R. Ma, M. Gao, H. Pan, Electrochem. Commun. 25, 15 (2012)

[27] H. Itahara, T. Yamada, S.Y. Oh, R. Asahi, H. Imagawa, H. Yamane, Chem. Commun. 50, 4315 (2014)

[28] A.G. Tamirat, M. Hou, Y. Liu, D. Bin, Y. Sun, L. Fan, Y. Wang, Y. Xia, J. Power Sources 384, 10 (2018)

[29] N.S. Nazer, R.V. Denys, H.F. Andersen, L. Arnberg, V.A. Yartys, J. Alloys Compd. 718, 478 (2017)

[30] D. Duveau, B. Fraisse, F. Cunin, L. Monconduit, Chem. Mater. 27, 3226 (2015)

[31] T. Song, H. Cheng, H. Choi, J.H. Lee, H. Han, D.H. Lee, D.S. Yoo, M.-S. Kwon, J.M. Choi, S.G. Doo, H. Chang, J. Xiao, Y. Huang, W. Il Park, Y.C. Chung, H. Kim, J.A. Rogers, U. Paik, ACS Nano 6, 303 (2012)

[32] K. Stokes, H. Geaney, G. Flynn, M. Sheehan, T. Kennedy, K.M. Ryan, ACS Nano 11, 10088 (2017)
[33] K. Stokes, G. Flynn, H. Geaney, G. Bree, K.M. Ryan, Nano Lett. 18, 5569 (2018)

[34] J. Yu, N. Du, J. Wang, H. Zhang, D. Yang, J. Alloys Compd. 577, 564 (2013)

[35] A. Netz, R.A. Huggins, W. Weppner, J. Power Sources 119-121, 95 (2003)

[36] S.M. Hwang, H.Y. Lee, S.W. Jang, S.M. Lee, S.J. Lee, H.K. Baik, J.Y. Lee, Electrochem. Solid State Lett. 4, A97 (2001)

[37] X. Wu, Z. Wang, L. Chen, X. Huang, Electrochem. Commun. 5, 935 (2003)

[38] H.T. Nguyen, M.R. Zamfir, L.D. Duong, Y.H. Lee, P. Bondavalli, D. Pribat, J. Mater. Chem. 22, 24618 (2012)

[39] K. Yao, M. Ling, G. Liu, W. Tong, J. Phys. Chem. Lett. 9, 5130 (2018)

[40] L.Y. Beaulieu, K.C. Hewitt, R.L. Turner, A. Bonakdarpour, A.A. Abdo, L. Christensen, K.W. Eberman, L.J. Krause, J.R. Dahn, J. Electrochem. Soc. 150, A149 (2003)

[41] J. Xu, M. Ling, L. Terborg, H. Zhao, F. Qiu, J.J. Urban, R. Kostecki, G. Liu, W. Tong, J. Electrochem. Soc. 164, A1378 (2017)

[42] X. Xiao, J.S. Wang, P. Liu, A.K. Sachdev, M.W. Verbrugge, D. Haddad, M.P. Balogh, J. Power Sources 214, 258 (2012)

[43] M.J. Loveridge, R. Malik, S. Paul, K.N. Manjunatha, S. Gallanti, C. Tan, M. Lain, A.J. Roberts, R. Bhagat, RSC Adv. 8, 16726 (2018)

[44] M. Salah, P. Murphy, C. Hall, C. Francis, R. Kerr, M. Fabretto, J. Power Sources 414, 48 (2019)

[45] D. Yang, J. Shi, J. Shi, H. Yang, Electrochim. Acta 259, 1081 (2018)

[46] L. Zhong, C. Beaudette, J. Guo, K. Bozhilov, L. Mangolini, Sci. Rep. 6, 1 (2016)

[47] Q. Hao, J. Hou, J. Ye, H. Yang, J. Du, C. Xu, Electrochim. Acta 306, 427 (2019)

[48] M. Zhang, L. Xiang, M. Galluzzi, C. Jiang, S. Zhang, J. Li, Y. Tang, Adv. Mater. 31, 1 (2019)

[49] M. Chen, M. Qi, J. Yin, Q. Chen, X. Xia, Mater. Res. Bull. 95, 414 (2017)

[50] Q. Zhang, J. Liu, Z.Y. Wu, J.T. Li, L. Huang, S.G. Sun, J. Alloys Compd. 657, 559 (2016)

[51] M.H. Tahmasebi, D. Kramer, H. Geßwein, T. Zheng, K.C. Leung, B.T.W. Lo, R. Mönig, S.T. Boles, J. Mater. Chem. A 8, $4877(2020)$

[52] K. Chang, D. Music, M. Strafela, S. Ulrich, J.M. Schneider, Solid State Ionics 303, 47 (2017)

[53] W. Li, X. Li, J. Liao, B. Zhao, L. Zhang, L. Huang, G. Liu, Z. Guo, M. Liu, Energy Environ. Sci. 12, 2286 (2019)

[54] R. Wibowo, S.E. Ward Jones, R.G. Compton, J. Phys. Chem. B 113, 12293 (2009)

[55] A.I. Bhatt, A.S. Best, J. Huang, A.F. Hollenkamp, J. Electrochem. Soc. 157, A66 (2010)

[56] Z. Wang, W.H. Tian, X.H. Liu, Y. Li, X.G. Li, Mater. Chem. Phys. 100, 92 (2006)

[57] X. Huang, H. Pu, J. Chang, S. Cui, P.B. Hallac, J. Jiang, P.T. Hurley, J. Chen, ACS Appl. Mater. Interfaces 5, 11965 (2013)

[58] X. Fan, H. Zhang, N. Du, P. Wu, X. Xu, Y. Li, D. Yang, Nanoscale 4, 5343 (2012)

[59] K. Kang, K. Song, H. Heo, S. Yoo, G.S. Kim, G. Lee, Y.M. Kang, M.H. Jo, Chem. Sci. 2, 1090 (2011)

[60] N. Du, X. Fan, J. Yu, H. Zhang, D. Yang, Electrochem. Commun. 13, 1443 (2011)

[61] H. Liu, L. Hu, Y.S. Meng, Q. Li, Nanoscale 5, 10376 (2013)

[62] F. Wang, S. Xu, S. Zhu, H. Peng, R. Huang, L. Wang, X. Xie, P.K. Chu, Electrochim. Acta 87, 250 (2013)

[63] H.Y. Lee, S.M. Lee, J. Power Sources 112, 649 (2002)

[64] W. He, Y. Liang, H. Tian, S. Zhang, Z. Meng, W.Q. Han, Energy Storage Mater. 8, 119 (2017) 
[65] Y. Nuli, B. Wang, J. Yang, X. Yuan, Z. Ma, J. Power Sources 153, 371 (2006)

[66] J.W. Kim, J.H. Ryu, K.T. Lee, S.M. Oh, J. Power Sources 147, $227(2005)$

[67] D.C. Johnson, J.M. Mosby, S.C. Riha, A.L. Prieto, J. Mater. Chem. 20, 1993 (2010)

[68] H. Song, H.X. Wang, Z. Lin, X. Jiang, L. Yu, J. Xu, Z. Yu, X. Zhang, Y. Liu, P. He, L. Pan, Y. Shi, H. Zhou, K. Chen, Adv. Funct. Mater. 26, 524 (2016)

[69] H. Song, S. Wang, X. Song, H. Yang, G. Du, L. Yu, J. Xu, P. He, H. Zhou, K. Chen, J. Mater. Chem. A 6, 7877 (2018)

[70] O. Park, J.I. Lee, M.J. Chun, J.T. Yeon, S. Yoo, S. Choi, N.S. Choi, S. Park, RSC Adv. 3, 2538 (2013)

[71] K.M. Lee, Y.S. Lee, Y.W. Kim, Y.K. Sun, S.M. Lee, J. Alloys Compd. 472, 461 (2009)

[72] S. Zhou, D. Wang, ACS Nano 4, 7014 (2010)

[73] S. Zhou, Z.I. Simpson, X. Yang, D. Wang, ACS Nano 6, 8114 (2012)

[74] S. Zhou, X. Liu, D. Wang, Nano Lett. 10, 860 (2010)

[75] S. Zhou, X. Yang, J. Xie, Z.I. Simpson, D. Wang, Chem. Commun. 49, 6470 (2013)

[76] S. Choi, J.C. Lee, O. Park, M.J. Chun, N.S. Choi, S. Park, J. Mater. Chem. A 1, 10617 (2013)

[77] F. Li, Z. Wang, W. Liu, T. Yan, C. Zhai, P. Wu, Y. Zhou, ACS Appl. Energy Mater. 2, 2268 (2019)

[78] P. Zuo, G. Yin, J. Alloys Compd. 414, 265 (2006)

[79] F.M. Courtel, D. Duguay, Y. Abu-Lebdeh, I.J. Davidson, J. Power Sources 202, 269 (2012)

[80] W. Peng, H. Guo, Z. Wang, X. Li, J. Wang, G. Yan, Y. Zhou, J. Electroanal. Chem. 826, 84 (2018)

[81] H. Jung, Y.U. Kim, M.S. Sung, Y. Hwa, G. Jeong, G.B. Kim, H.J. Sohn, J. Mater. Chem. 21, 11213 (2011)

[82] S.B. Son, S.C. Kim, C.S. Kang, T.A. Yersak, Y.C. Kim, C.G. Lee, S.H. Moon, J.S. Cho, J.T. Moon, K.H. Oh, S.H. Lee, Adv. Energy Mater. 2, 1226 (2012)

[83] H.J. Kwon, K.Y. Sohn, W.W. Park, Electron. Mater. Lett. 9, 859 (2013)

[84] A. Ladam, N. Bibent, C. Cénac-Morthé, L. Aldon, J. OlivierFourcade, J.C. Jumas, P.E. Lippens, Electrochim. Acta 245, 497 (2017)

[85] T. Song, K.C. Kil, Y. Jeon, S. Lee, W.C. Shin, B. Chung, K. Kwon, U. Paik, J. Power Sources 253, 282 (2014)

[86] M. Kim, J.W. Kim, M.S. Sung, Y. Hwa, S.H. Kim, H.J. Sohn, J. Electroanal. Chem. 687, 84 (2012)

[87] M.R. Jo, Y.-U. Heo, Y.C. Lee, Y.M. Kang, Nanoscale 6, 1005 (2014)

[88] M.S. Park, Y.M. Kang, S. Rajendran, H.S. Kwon, J.Y. Lee, Mater. Chem. Phys. 100, 496 (2006)

[89] C. Lu, Y. Fan, H. Li, Y. Yang, B.K. Tay, E. Teo, Q. Zhang, Carbon N. Y. 63, 54 (2013)

[90] K. Wang, X. He, L. Wang, J. Ren, C. Jiang, C. Wan, Solid State Ion. 178, 115 (2007)

[91] T. Li, Y.L. Cao, X.P. Ai, H.X. Yang, J. Power Sources 184, 473 (2008)

[92] Y.S. Lee, J.H. Lee, Y.W. Kim, Y.K. Sun, S.M. Lee, Electrochim. Acta 52, 1523 (2006)

[93] S. Yoon, C.M. Park, H. Kim, H.J. Sohn, J. Power Sources 167, 520 (2007)

[94] Y. Kwon, H. Kim, S.G. Doo, J. Cho, Chem. Mater. 19, 982 (2007)
[95] W. Zhou, S. Upreti, M.S. Whittingham, Electrochem. Commun. 13, 158 (2011)

[96] Z. Edfouf, F. Cuevas, M. Latroche, C. Georges, C. Jordy, T. Hézèque, G. Caillon, J.C. Jumas, M.T. Sougrati, J. Power Sources 196, 4762 (2011)

[97] J. Qu, Y. Yan, Y.X. Yin, Y.G. Guo, W.G. Song, ACS Appl. Mater. Interfaces 5, 5777 (2013)

[98] M. Ruttert, V. Siozios, M. Winter, T. Placke, A.C.S. Appl, Energy Mater. 3, 743 (2020)

[99] N. Fukata, M. Mitome, Y. Bando, W. Wu, Z.L. Wang, Nano Energy 26, 37 (2016)

[100] H. Jia, C. Stock, R. Kloepsch, X. He, J.P. Badillo, O. Fromm, B. Vortmann, M. Winter, T. Placke, ACS Appl. Mater. Interfaces 7, $1508(2015)$

[101] Q. Zhang, H. Chen, L. Luo, B. Zhao, H. Luo, X. Han, J. Wang, C. Wang, Y. Yang, T. Zhu, M. Liu, Energy Environ. Sci. 11, 669 (2018)

[102] S. Yin, D. Zhao, Q. Ji, Y. Xia, S. Xia, X. Wang, M. Wang, J. Ban, Y. Zhang, E. Metwalli, X. Wang, Y. Xiao, X. Zuo, S. Xie, K. Fang, S. Liang, L. Zheng, B. Qiu, Z. Yang, Y. Lin, L. Chen, C. Wang, Z. Liu, J. Zhu, P. Müller-Buschbaum, Y.J. Cheng, ACS Nano 12, 861 (2018)

[103] N. Umirov, D.H. Seo, T. Kim, H.Y. Kim, S.S. Kim, J. Ind. Eng. Chem. 71, 351 (2019)

[104] Z. Chen, J. Ye, R. Qin, Q. Hao, C. Xu, J. Hou, Int. J. Hydrog. Energy 44, 1078 (2019)

[105] H.T. Kwon, A.R. Park, S.S. Lee, H. Cho, H. Jung, C.M. Park, J. Electrochem. Soc. 166, A2221 (2019)

[106] S. Yoon, S. Il Lee, H. Kim, H.J. Sohn, J. Power Sources 161, 1319 (2006)

[107] X. Wang, Z. Wen, Y. Liu, L. Huang, M. Wu, J. Alloys Compd. 506, 317 (2010)

[108] A.R. Park, J.S. Kim, K.S. Kim, K. Zhang, J. Park, J.H. Park, J.K. Lee, P.J. Yoo, ACS Appl. Mater. Interfaces 6, 1702 (2014)

[109] A.R. Park, M.G. Nam, A.Y. Kim, K.S. Kim, M.S.A. Sher Shah, J.Y. Lee, W.J. Kim, J.K. Lee, P.J. Yoo, J. Alloys Compd. 724, 1134 (2017)

[110] W. Xiao, J. Zhou, L. Yu, D. Wang, X.W. Lou, Angew. Chem. Int. Ed. 55, 7427 (2016)

[111] J. Ahn, B. Kim, G. Jang, J. Moon, ChemElectroChem 5, 2729 (2018)

[112] A. Desrues, J.P. Alper, F. Boismain, D. Zapata Dominguez, C. Berhaut, P. Coulon, A. Soloy, F. Grisch, S. Tardif, S. Pouget, S. Lyonnard, C. Haon, N. Herlin-Boime, Batter. Supercaps 2, 970 (2019)

[113] F. Li, H. Yue, P. Wang, Z. Yang, D. Wang, D. Liu, L. Qiao, D. He, CrystEngComm 15, 7298 (2013)

[114] J. Yu, N. Du, H. Zhang, D. Yang, RSC Adv. 3, 7713 (2013)

[115] X. Han, H. Chen, X. Li, S. Lai, Y. Xu, C. Li, S. Chen, Y. Yang, ACS Appl. Mater. Interfaces 8, 673 (2016)

[116] X.H. Huang, P. Zhang, J.B. Wu, Y. Lin, R.Q. Guo, Mater. Res. Bull. 80, 30 (2016)

[117] M. Chen, Q.S. Jing, H. Bin Sun, J.Q. Xu, Z.Y. Yuan, J.T. Ren, A.X. Ding, Z.Y. Huang, M.Y. Dong, Langmuir 35, 6321 (2019)

[118] C. Liu, Y. Zhao, R. Yi, Y. Sun, Y. Li, L. Yang, I. Mitrovic, S. Taylor, P. Chalker, C. Zhao, Electrochim. Acta 306, 45 (2019)

[119] L. Sun, X. Wang, R.A. Susantyoko, Q. Zhang, J. Mater. Chem. A 2, 15294 (2014)

[120] P.K. Lee, M.H. Tahmasebi, S. Ran, S.T. Boles, D.Y.W. Yu, Small 14, 1 (2018) 